\title{
Mycotoxins in Poultry Feed and Feed Ingredients from Sub-Saharan Africa and Their Impact on the Production of Broiler and Layer Chickens: A Review
}

\author{
Phillis E. Ochieng ${ }^{1,2}$, Marie-Louise Scippo ${ }^{1}$, David C. Kemboi ${ }^{2,3,4}$, Siska Croubels ${ }^{2} ®$, Sheila Okoth ${ }^{5}($, \\ Erastus K. Kang' ethe ${ }^{6}$, Barbara Doupovec ${ }^{7}$, James K. Gathumbi ${ }^{3}$, Johanna F. Lindahl ${ }^{8,9,10}$ (D) \\ and Gunther Antonissen 2,11,*(D)
}

check for updates

Citation: Ochieng, P.E.; Scippo, M.-L.; Kemboi, D.C.; Croubels, S.; Okoth, S.; Kang'ethe, E.K.; Doupovec, B.; Gathumbi, J.K.; Lindahl, J.F.; Antonissen, G. Mycotoxins in Poultry Feed and Feed Ingredients from Sub-Saharan Africa and Their Impact on the Production of Broiler and Layer Chickens: A Review. Toxins 2021, 13, 633. https://doi.org/ $10.3390 /$ toxins 13090633

Received: 9 August 2021

Accepted: 3 September 2021

Published: 8 September 2021

Publisher's Note: MDPI stays neutral with regard to jurisdictional claims in published maps and institutional affiliations.

Copyright: (C) 2021 by the authors. Licensee MDPI, Basel, Switzerland. This article is an open access article distributed under the terms and conditions of the Creative Commons Attribution (CC BY) license (https:// creativecommons.org/licenses/by/ $4.0 /)$.
1 Laboratory of Food Analysis, FARAH-Veterinary Public Health, University of Liège, Avenue de Cureghem 10, 4000 Liège, Belgium; peochieng@uliege.be (P.E.O.); mlscippo@ulg.ac.be (M.-L.S.)

2 Department of Pharmacology, Toxicology and Biochemistry, Faculty of Veterinary Medicine, Ghent University, Salisburylaan 133, 9820 Merelbeke, Belgium; David.Kemboi@UGent.be (D.C.K.); Siska.Croubels@UGent.be (S.C.)

3 Department of Pathology, Microbiology and Parasitology, Faculty of Veterinary Medicine, University of Nairobi, P.O. Box 29053, Nairobi 00100, Kenya; jkgathumbi@uonbi.ac.ke

4 Department of Animal Science, Chuka University, P.O. Box 109-00625, Chuka 00625, Kenya

5 School of Biological Sciences, University of Nairobi, P.O. Box 30197, Nairobi 00100, Kenya; sheilaokoth@uonbi.ac.ke

6 Independent Researcher, P.O. Box 34405, Nairobi 00100, Kenya; mburiajudith@gmail.com

7 BIOMIN Research Center, Technopark 1,3430 Tulln, Austria; barbara.doupovec@dsm.com

8 Department of Biosciences, International Livestock Research Institute (ILRI), P.O. Box 30709, Nairobi 00100, Kenya; J.Lindahl@cgiar.org

9 Department of Medical Biochemistry and Microbiology, Uppsala University, P.O. Box 582, 75123 Uppsala, Sweden

10 Department of Clinical Sciences, Swedish University of Agricultural Sciences, P.O Box 7054, 75007 Uppsala, Sweden

11 Department of Pathology, Bacteriology and Avian Diseases, Faculty of Veterinary Medicine, Ghent University, Salisburylaan 133, 9820 Merelbeke, Belgium

* Correspondence: Gunther.Antonissen@ugent.be

Abstract: The poultry industry in sub-Saharan Africa (SSA) is faced with feed insecurity, associated with high cost of feeds, and feed safety, associated with locally produced feeds often contaminated with mycotoxins. Mycotoxins, including aflatoxins (AFs), fumonisins (FBs), trichothecenes, and zearalenone (ZEN), are common contaminants of poultry feeds and feed ingredients from SSA. These mycotoxins cause deleterious effects on the health and productivity of chickens and can also be present in poultry food products, thereby posing a health hazard to human consumers of these products. This review summarizes studies of major mycotoxins in poultry feeds, feed ingredients, and poultry food products from SSA as well as aflatoxicosis outbreaks. Additionally reviewed are the worldwide regulation of mycotoxins in poultry feeds, the impact of major mycotoxins in the production of chickens, and the postharvest use of mycotoxin detoxifiers. In most studies, AFs are most commonly quantified, and levels above the European Union regulatory limits of $20 \mu \mathrm{g} / \mathrm{kg}$ are reported. Trichothecenes, FBs, ZEN, and OTA are also reported but are less frequently analyzed. Co-occurrences of mycotoxins, especially AFs and FBs, are reported in some studies. The effects of AFs on chickens' health and productivity, carryover to their products, as well as use of mycotoxin binders are reported in few studies conducted in SSA. More research should therefore be conducted in SSA to evaluate occurrences, toxicological effects, and mitigation strategies to prevent the toxic effects of mycotoxins.

Keywords: aflatoxins; co-occurrence; eggs; fumonisins; mycotoxicosis; poultry feeds

Key Contribution: This paper summarizes studies on occurrences of major mycotoxins in poultry feeds and feed ingredients from sub-Saharan Africa. The effects of mycotoxins on poultry health and performance and carryover to poultry products are also discussed. The paper also contributes to 
knowledge on the postharvest use of mycotoxin-detoxifying agents to reduce the negative effects of mycotoxins in layer and broiler productions.

\section{Introduction}

The poultry industry in sub-Saharan Africa (SSA) is an essential subsector of agriculture, providing food, employment, and other economic resources for the region. As an example, over $80 \%$ of households in Ethiopia and Swaziland are reported to practice poultry farming at small-scale levels, as it requires less space compared with other livestock, such as dairy and pigs [1,2]. Poultry and fish proteins contribute over $60 \%$ of the human protein intake in SSA, and demand for animal proteins is projected to increase due to the rapid growth of the human population, which is projected to be 2.2 billion by 2050 [3]. Furthermore, urbanization and increases in gross domestic product (GDP) also contribute to the demand for animal source foods [4]. Poultry production in Southern and Eastern African countries have gradually grown over the past decades to commercial poultry value chains that include feed suppliers, hatcheries, housing, and slaughtering equipment, as well as veterinary services [5]. This growth in production systems will inevitably become more intensive and thereby increase the demand for high-quality poultry feeds.

Poultry feeds in SSA, similar to other parts of the world, consist of animal protein sources, such as fish meal, meat, and bone meal, whereas major plant protein sources include soybean meal, cotton seed, sunflower seed cake, and peanut products, with maize serving as the main source of energy [6]. Fish meal and soybean meal are the conventional protein sources and currently becoming scarce and expensive, thereby making poultry feeds costly and accounting for approximately $60 \%$ to $80 \%$ of the total production cost [7]. In addition, feed ingredients have been shown to be prone to contamination by mycotoxins, resulting in contamination of final poultry feed commodities $[6,8]$.

Mycotoxins are secondary metabolites of fungi mainly belonging to the genera Aspergillus, Alternaria, Fusarium, Cladosporium, Claviceps, and Penicillium [9]. More than 400 mycotoxins have been reported in food and feed. The most frequently detected, and of concern globally, are aflatoxin B1 (AFB1), aflatoxin B2 (AFB2), aflatoxin G1 (AFG1), and aflatoxin G2 (AFG2); fumonisins (FBs); trichothecenes (for example, deoxynivalenol (DON) and T-2 toxin (T-2)); and ochratoxin A (OTA) [10]. These toxins are reported to cause economic losses, diseases, and even the death of humans and animals. In SSA, the risk of food and feed contamination with mycotoxins has been reported to be considerably high as adequate control and good storage are difficult to achieve [11,12]. Climatic conditions in most regions in SSA are characterized by high relative humidity, high temperatures, and little aeration [13]. These conditions make crops more liable to mycotoxin contaminations as they accelerate growth and mycotoxin biosynthesis by toxigenic fungi. Although the focus of mycotoxin risk assessment and management in developing countries is on food safety, given the direct links between feed safety, food production, and the safety of animal food products, it is essential that feed production and manufacturing procedures meet safety requirements. This review summarizes occurrences of mycotoxins in poultry feed and feed ingredients from SSA over the last 23 years (between the years 1998 and 2021). Worldwide regulations of mycotoxins in poultry feeds and the impact of mycotoxins on layer and broiler chickens' production as well as the use of mycotoxin binders as postharvest mycotoxin mitigation strategies are also reviewed.

\section{Worldwide Regulation of Mycotoxins in Poultry Feeds}

In Africa, only 6 countries out of 54 and 1 region (East African Community, (EAC)) had regulatory limits for AFs in poultry feeds (Table 1) at the time of their review. South Africa was the only country with guidance values for OTA, FBs, and DON in poultry feeds, in addition to regulatory limits for AFs [6]. The East African Community, a regional intergovernmental organization, has set the maximum limit for total AFs at $50 \mu \mathrm{g} / \mathrm{kg}$ 
and AFB1 at $20 \mu \mathrm{g} / \mathrm{kg}$ for adult poultry feeds [14]. Most African regional and national mycotoxin regulatory limits are established and enforced due to trade and the desire to comply with export regulations $[14,15]$. The European Union (EU) has regulations and guidance values for mycotoxins in feeds for different animal species and has established regulatory limits for AFB1 and guidance values for total FBs, DON, ZEN, and OTA in poultry feeds (Table 1) [16]. On the other hand, the Canadian Food Inspection Agency (CFIA) set guidance values for both OTA and T-2 in poultry feed at levels higher than those recommended by the EU [17]. Similarly, the United States of America has set higher guidance values for DON and FBs in poultry feeds as compared with those set by the EU [18].

Table 1. Worldwide regulations of mycotoxins in poultry feeds.

\begin{tabular}{|c|c|c|c|c|c|c|c|c|}
\hline \multirow[t]{2}{*}{ Country/Region } & \multicolumn{2}{|c|}{ Regulatory Limit ( $\mu \mathrm{g} / \mathrm{kg})$} & \multicolumn{5}{|c|}{ Guidance Value ( $\mu \mathrm{g} / \mathrm{kg})$} & \multirow[t]{2}{*}{ Reference } \\
\hline & AFB1 & Total AFs & DON & FBs & ZEN & $\mathrm{T}-2$ & OTA & \\
\hline Côte d'Ivoire & - & 10 & - & - & - & - & - & [19] \\
\hline Ghana & - & 15 & - & - & - & - & - & {$[4]$} \\
\hline Senegal & 50 & - & - & - & - & - & - & [19] \\
\hline South Africa & - & 20 & 4000 & 50,000 & - & - & 20 & [6] \\
\hline Tanzania & 5 & 10 & - & - & - & - & - & [14] \\
\hline Zimbabwe & - & 10 & - & - & - & - & - & [19] \\
\hline EAC & 20 & 50 & - & - & - & - & - & [14] \\
\hline CFIA & - & - & - & - & - & 1000 & 2000 & [17] \\
\hline $\mathrm{EU}$ & 20 & - & 5000 & 20,000 & 250 & 250 & 100 & [16] \\
\hline USA & 20 & - & 10,000 & 30,000 & - & - & - & [18] \\
\hline
\end{tabular}

Total AFs—sum of aflatoxin B1 (AFB1), aflatoxin B2 (AFB2), aflatoxin G1(AFG1), and aflatoxin G2 (AFG2); DON—deoxynivalenol; FBs— fumonisins; ZEN-zearalenone; T-2-T-2 toxin; HT-2-HT-2 toxin; OTA-ochratoxin A; CFIA —Canadian Food Inspection Agency; EACEast African Community; EU—European Union; USA-United States of America; -means no reported regulatory limit or guidance value.

\section{Occurrence of Major Mycotoxins in Poultry Feed and Feed Ingredients from SSA}

Few studies have been conducted to determine mycotoxins in poultry feeds and poultry feed ingredients, with AFs being the most determined mycotoxins (Table 2). 
Table 2. Occurrences of major mycotoxins in poultry feeds and feed ingredients from SSA.

\begin{tabular}{|c|c|c|c|c|c|c|c|c|c|c|}
\hline \multicolumn{11}{|c|}{ Aflatoxins } \\
\hline Mycotoxin & Country & Type of Sample & $\begin{array}{l}\text { Analytical } \\
\text { Technique }\end{array}$ & $\begin{array}{l}\text { LOD } \\
(\mu \mathrm{g} / \mathrm{kg})\end{array}$ & $\%$ Positive $(n)$ & $\begin{array}{l}\text { \% Above EU } \\
\text { Limit }\end{array}$ & $\operatorname{Max}(\mu \mathrm{g} / \mathrm{kg})$ & $\begin{array}{c}\text { Mean } \\
(\mu \mathrm{g} / \mathrm{kg})\end{array}$ & $\begin{array}{c}\text { Year of } \\
\text { Publication }\end{array}$ & Reference \\
\hline \multirow{16}{*}{ AFs } & \multirow{2}{*}{ Botswana } & Poultry feed ingredients: peanut & $\begin{array}{l}\text { TLC and } \\
\text { HPLC-FLD }\end{array}$ & \multirow{2}{*}{0.10} & $52 \%(29)$ & & 48.01 & 14.0 & \multirow{2}{*}{1998} & \multirow{2}{*}[20]{} \\
\hline & & Poultry feeds & & & $100 \%(4)$ & & 0.7 & 0.6 & & \\
\hline & \multirow[b]{2}{*}{ Cameroon } & Poultry feeds: broiler feeds & \multirow[b]{2}{*}{ Fluorimeter } & \multirow[b]{2}{*}{2.00} & $93 \%(30)$ & & 52.0 & 11.1 & \multirow[b]{2}{*}{2013} & \multirow[b]{2}{*}{ [13] } \\
\hline & & $\begin{array}{l}\text { Poultry feed ingredients: } \\
\text { peanut meal }\end{array}$ & & & $100 \%(41)$ & $90 \%$ & 950.0 & 161.4 & & \\
\hline & \multirow{3}{*}{ Ethiopia } & \multirow{3}{*}{$\begin{array}{l}\text { Poultry feed ingredients: maize } \\
\text { Poultry feed ingredients: } \\
\text { groundnut } \\
\text { Poultry feed ingredients: maize }\end{array}$} & ELISA & 1.75 & $88 \%(17)$ & \multirow[t]{2}{*}{$6 \%$} & 27.0 & & 2010 & [21] \\
\hline & & & ELISA & 1.75 & $93 \%(120)$ & & $11,900.0$ & & 2013 & [22] \\
\hline & & & LFIA & 3.30 & $100 \%(150)$ & $5 \%$ & 150.0 & 14.7 & 2019 & [23] \\
\hline & Ghana & Poultry feeds & LFIA & 3.30 & $100 \%(350)$ & $74 \%$ & 118.0 & 57.3 & 2021 & [4] \\
\hline & Kenya & $\begin{array}{l}\text { Poultry feed ingredients } \\
\text { Poultry feeds }\end{array}$ & LC-MS/MS & 0.10 & $\begin{array}{l}29 \%(24) \\
93 \%(27)\end{array}$ & $15 \%$ & $\begin{array}{l}99.4 \\
89.0\end{array}$ & $\begin{array}{l}38.9 \\
17.2\end{array}$ & 2020 & [10] \\
\hline & Rwanda & Poultry feeds & ELISA & 5.00 & $52 \%(1726)$ & & & 103.8 & 2019 & [14] \\
\hline & \multirow{2}{*}{$\begin{array}{l}\text { South } \\
\text { Africa }\end{array}$} & Poultry feeds & $\begin{array}{l}\text { UHPLC- } \\
\text { MS/MS }\end{array}$ & 0.10 & $23 \%(62)$ & & 1.8 & 0.7 & 2012 & {$[6]$} \\
\hline & & Poultry feed ingredients: maize & LC-MS/MS & 0.20 & $10 \%(282)$ & & 14.0 & & 2018 & [25] \\
\hline & \multirow[t]{2}{*}{ Tanzania } & $\begin{array}{l}\text { Poultry feed ingredients: } \\
\text { sunflower cakes } \\
\text { Poultry feed ingredients: } \\
\text { sunflower seeds }\end{array}$ & ELISA & 1.40 & $\begin{array}{l}80 \%(92) \\
59 \%(90)\end{array}$ & $\begin{array}{l}17 \% \\
14 \%\end{array}$ & $\begin{array}{l}598.4 \\
662.7\end{array}$ & & 2017 & [26] \\
\hline & & $\begin{array}{l}\text { Poultry feed ingredients: maize } \\
\text { and maize-based products }\end{array}$ & ELISA & 2.00 & $32 \%(160)$ & & 16.2 & 3.4 & 2016 & [27] \\
\hline & \multirow[b]{2}{*}{ Uganda } & \multirow{2}{*}{$\begin{array}{c}\text { Poultry feeds } \\
\text { Poultry feed ingredients: } \\
\text { Maize bran }\end{array}$} & \multirow[t]{2}{*}{ Fluorimeter } & \multirow[b]{2}{*}{1.00} & $100 \%(67)$ & $82 \%$ & 393.5 & & 2020 & \multirow[b]{2}{*}{ [11] } \\
\hline & & & & & $100 \%(4)$ & & 103.3 & & & \\
\hline
\end{tabular}


Table 2. Cont.

\begin{tabular}{|c|c|c|c|c|c|c|c|c|c|c|}
\hline \multicolumn{11}{|c|}{ Aflatoxins } \\
\hline Mycotoxin & Country & Type of Sample & $\begin{array}{l}\text { Analytical } \\
\text { Technique }\end{array}$ & $\begin{array}{l}\text { LOD } \\
(\mu \mathrm{g} / \mathrm{kg})\end{array}$ & \% Positive $(n)$ & $\begin{array}{l}\% \text { Above EU } \\
\text { Limit }\end{array}$ & $\operatorname{Max}(\mu \mathrm{g} / \mathrm{kg})$ & $\begin{array}{c}\text { Mean } \\
(\mu \mathrm{g} / \mathrm{kg})\end{array}$ & $\begin{array}{c}\text { Year of } \\
\text { Publication }\end{array}$ & Reference \\
\hline \multirow{11}{*}{ AFB1 } & Benin & $\begin{array}{l}\text { Poultry feed ingredients: peanut } \\
\text { cake }\end{array}$ & LC-MS/MS & 2.00 & $100 \%(15)$ & & 282.0 & & 2011 & [28] \\
\hline & \multirow{2}{*}{ Ethiopia } & Poultry feed ingredients: maize & LC-MS/MS & 0.30 & $8 \%(100)$ & \multirow[b]{2}{*}{$34 \%$} & 513.0 & \multirow[t]{2}{*}{9.3} & 2018 & [29] \\
\hline & & Poultry feed ingredients: maize & ELISA & 1.75 & $34 \%(90)$ & & 381.6 & & 2019 & [30] \\
\hline & Kenya & $\begin{array}{c}\text { Poultry feeds } \\
\text { Poultry feed ingredients }\end{array}$ & LC-MS/MS & 0.20 & $\begin{array}{l}93 \%(27) \\
25 \%(24)\end{array}$ & $15 \%$ & $\begin{array}{l}38.8 \\
49.8\end{array}$ & $\begin{array}{l}10.2 \\
19.7\end{array}$ & 2020 & [10] \\
\hline & \multirow{6}{*}{ Nigeria } & Poultry feeds & LC-MS/MS & 4.00 & $76 \%(58)$ & $62 \%$ & 1067.0 & 198.0 & 2012 & [31] \\
\hline & & Poultry feeds & \multirow{4}{*}{ LC-MS/MS } & & $83 \%(30)$ & & 760.0 & 74.0 & \multirow{4}{*}{2018} & \\
\hline & & Poultry feed ingredients: maize & & & $47 \%(17)$ & & 567.0 & 176.0 & & \multirow{3}{*}[8]{} \\
\hline & & $\begin{array}{l}\text { Poultry feed ingredients: } \\
\text { peanut cake }\end{array}$ & & & $91 \%(11)$ & & 3860.0 & 639.0 & & \\
\hline & & $\begin{array}{l}\text { Poultry feed ingredients: } \\
\text { wheat offal }\end{array}$ & & & $30 \%(10)$ & & 80.0 & 53.0 & & \\
\hline & & $\begin{array}{l}\text { Poultry feed ingredients: } \\
\text { peanut meal }\end{array}$ & LC-MS/MS & 2.00 & $100 \%(29)$ & $90 \%$ & 2820.0 & & 2012 & [32] \\
\hline & $\begin{array}{l}\text { South } \\
\text { Africa }\end{array}$ & Poultry feeds & $\begin{array}{l}\text { UHPLC- } \\
\text { MS/MS }\end{array}$ & 0.04 & $93 \%(105)$ & & 0.9 & 0.2 & 2019 & [33] \\
\hline \multirow{7}{*}{ AFB2 } & \multirow{2}{*}{ Kenya } & Poultry feed ingredients & LC-MS/MS & \multirow[b]{2}{*}{0.06} & $17 \%(24)$ & & 7.0 & 3.4 & 2020 & \multirow{2}{*}{ [10] } \\
\hline & & Poultry feeds & & & $48 \%(27)$ & & 4.4 & 1.7 & & \\
\hline & \multirow{4}{*}{ Nigeria } & Poultry feeds & LC-MS/MS & \multirow[t]{4}{*}{10.00} & $50 \%(58)$ & & 114.0 & 34.0 & 2012 & \multirow[t]{3}{*}{ [31] } \\
\hline & & Poultry feeds & \multirow[t]{3}{*}{ LC-MS/MS } & & $50 \%(30)$ & & 188.0 & 21.0 & 2018 & \\
\hline & & \multirow{2}{*}{$\begin{array}{l}\text { Poultry feed ingredients: maize } \\
\text { Poultry feed ingredients: } \\
\text { peanut cake }\end{array}$} & & & $24 \%(17)$ & & 61.0 & 35.0 & & \\
\hline & & & & & $91 \%(11)$ & & 895.0 & 126.0 & & [8] \\
\hline & $\begin{array}{l}\text { South } \\
\text { Africa }\end{array}$ & Poultry feeds & $\begin{array}{l}\text { UHPLC- } \\
\text { MS/MS }\end{array}$ & 0.02 & $100 \%(105)$ & & 7.1 & 0.4 & 2019 & [33] \\
\hline
\end{tabular}


Table 2. Cont.

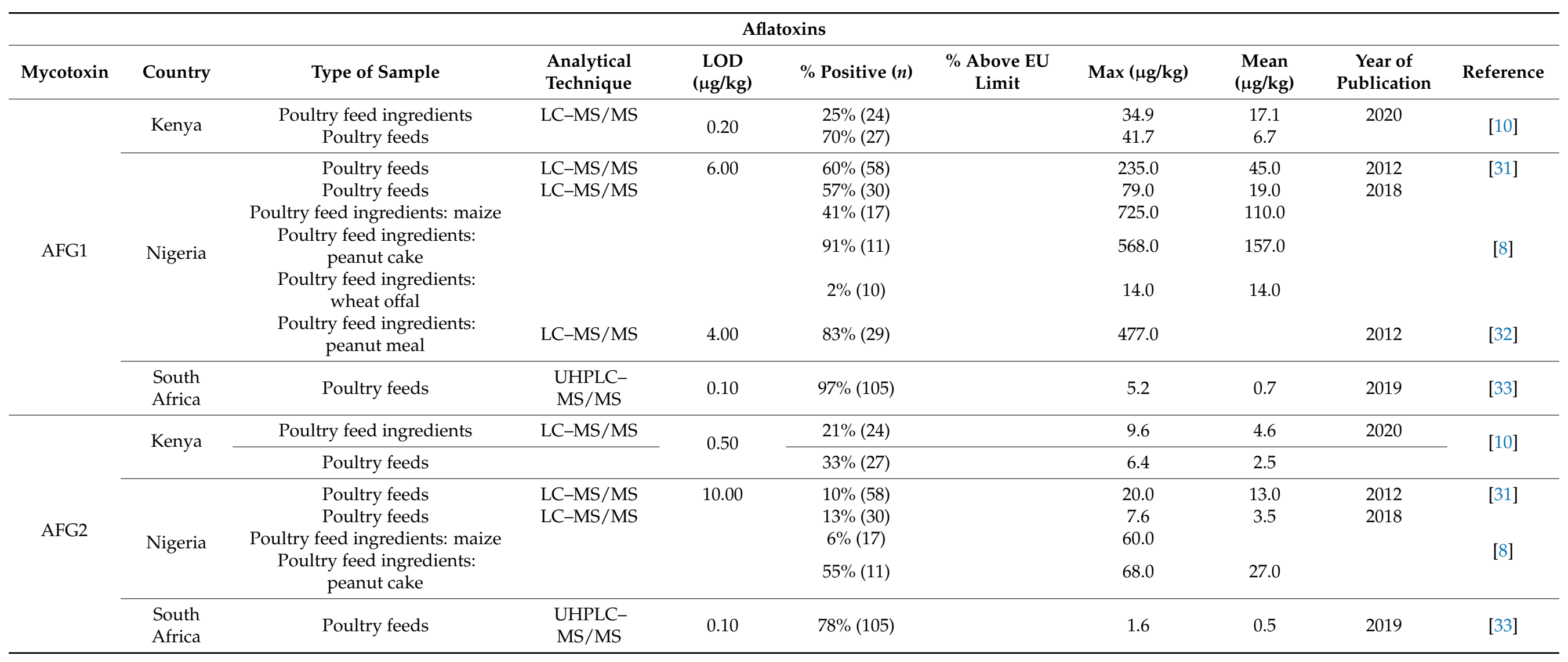


Table 2. Cont.

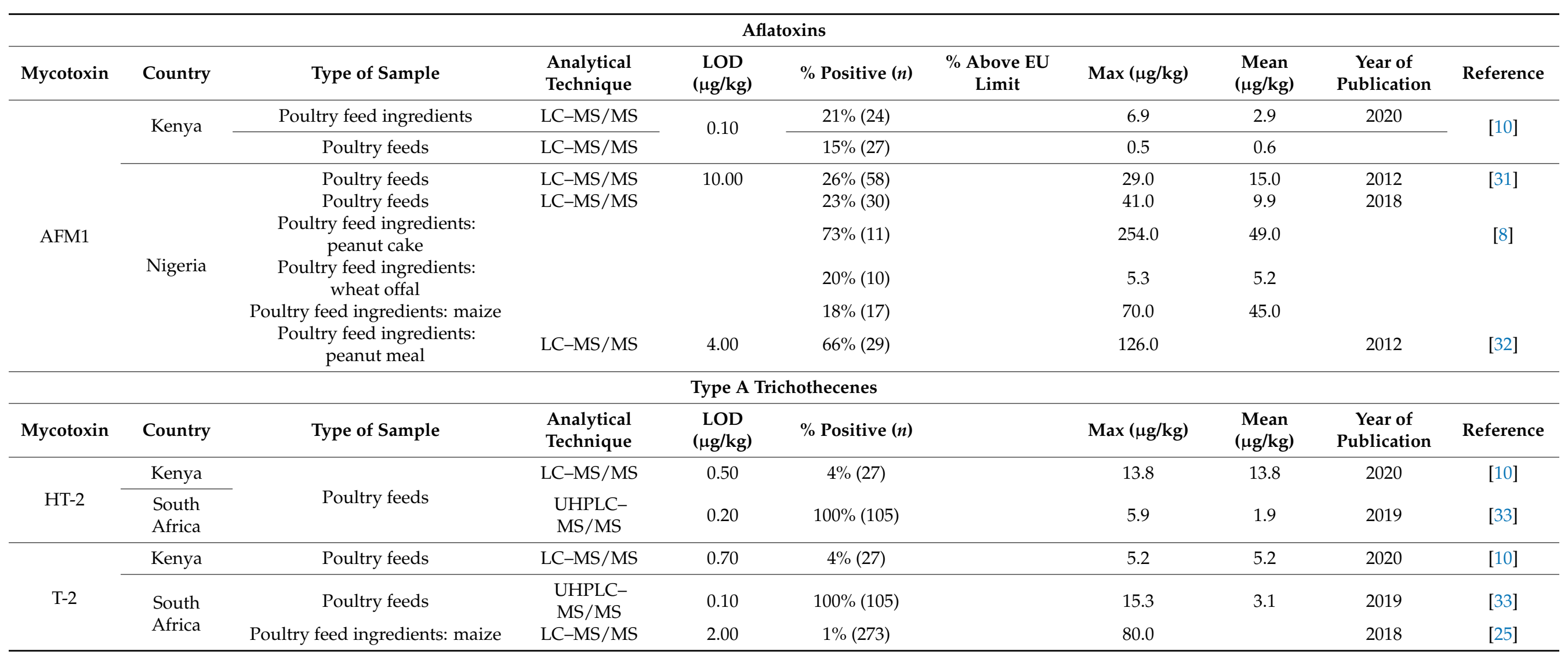


Table 2. Cont.

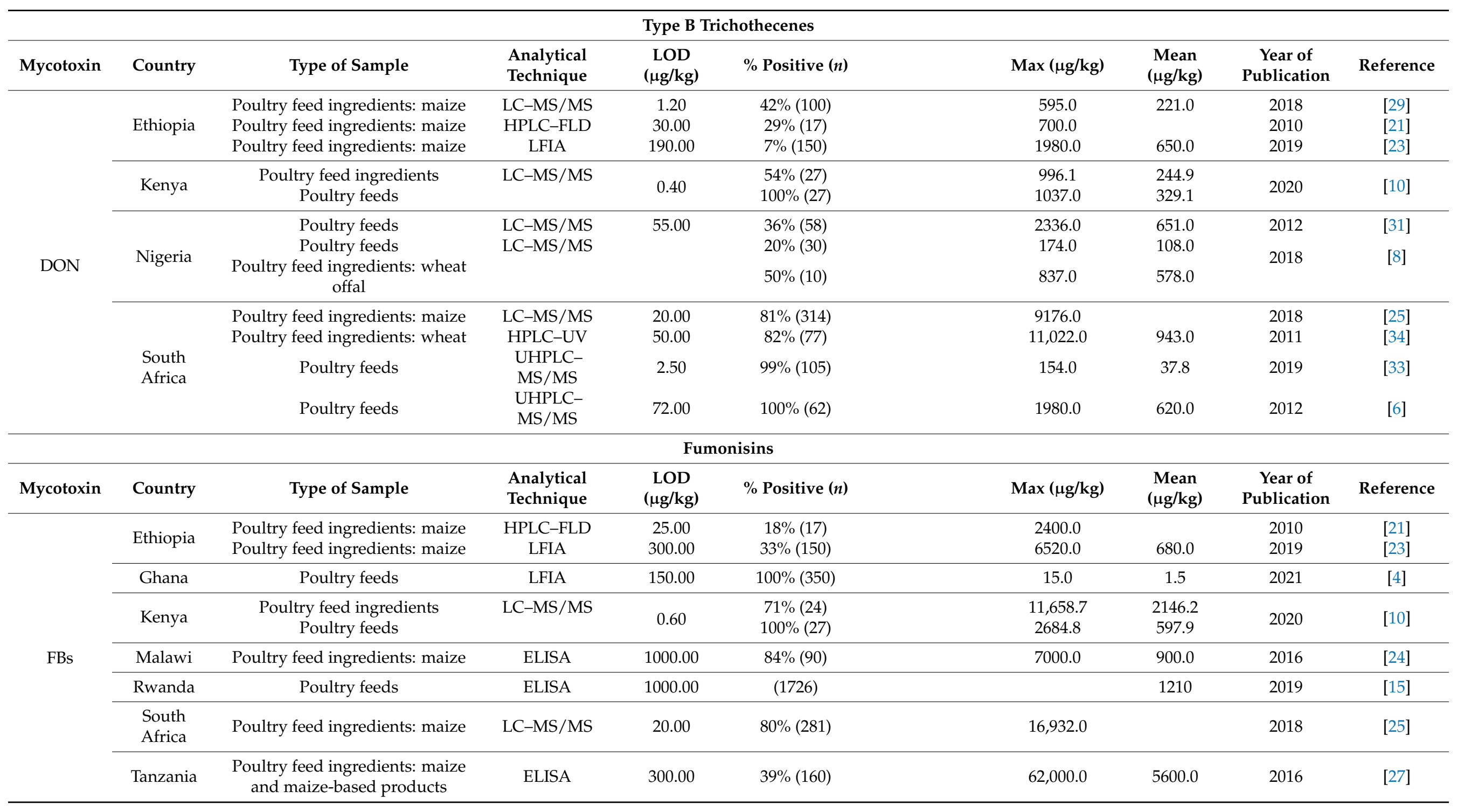


Table 2. Cont.

\begin{tabular}{|c|c|c|c|c|c|c|c|c|c|}
\hline \multicolumn{10}{|c|}{ Fumonisins } \\
\hline Mycotoxin & Country & Type of Sample & $\begin{array}{l}\text { Analytical } \\
\text { Technique }\end{array}$ & $\begin{array}{l}\text { LOD } \\
(\mu \mathrm{g} / \mathrm{kg})\end{array}$ & $\%$ Positive $(n)$ & $\operatorname{Max}(\mu \mathrm{g} / \mathrm{kg})$ & $\begin{array}{c}\text { Mean } \\
(\mu \mathrm{g} / \mathrm{kg})\end{array}$ & $\begin{array}{c}\text { Year of } \\
\text { Publication }\end{array}$ & Reference \\
\hline \multirow{11}{*}{ FB1 } & Benin & $\begin{array}{l}\text { Poultry feed ingredients: peanut } \\
\text { cake }\end{array}$ & LC-MS/MS & 1.00 & $7 \%(15)$ & 80.0 & & 2011 & [28] \\
\hline & \multirow{2}{*}{ Botswana } & Poultry feed ingredients: maize & $\begin{array}{l}\text { TLC and } \\
\text { HPLC-FLD }\end{array}$ & \multirow{2}{*}{20.00} & $85 \%(33)$ & 1270.0 & 247.0 & \multirow{2}{*}{1998} & \multirow{2}{*}[20]{} \\
\hline & & Poultry feeds & & & $100 \%(4)$ & 1050.0 & 572.0 & & \\
\hline & Kenya & $\begin{array}{l}\text { Poultry feed ingredients } \\
\text { Poultry feeds }\end{array}$ & LC-MS/MS & 2.00 & $\begin{array}{c}71 \%(24) \\
100 \%(27)\end{array}$ & $\begin{array}{l}8345.6 \\
1926.0\end{array}$ & $\begin{array}{c}1474.4 \\
431.4\end{array}$ & 2020 & [10] \\
\hline & \multirow{5}{*}{ Nigeria } & Poultry feeds & LC-MS/MS & \multirow[t]{5}{*}{40.00} & $83 \%(58)$ & 2733.0 & 964.0 & \multirow[t]{3}{*}{2012} & \multirow[t]{3}{*}{ [31] } \\
\hline & & Poultry feeds & LC-MS/MS & & $97 \%(30)$ & 3760.0 & 1014.0 & & \\
\hline & & Poultry feed ingredients: maize & & & $100 \%(17)$ & 2090.0 & 825.0 & & \\
\hline & & $\begin{array}{l}\text { Poultry feed ingredients: peanut } \\
\text { cake }\end{array}$ & & & $27 \%(11)$ & 910.0 & 308.0 & 2018 & [8] \\
\hline & & $\begin{array}{c}\text { Poultry feed ingredients: wheat } \\
\text { offal }\end{array}$ & & & $50 \%(10)$ & 67.0 & 37.0 & & \\
\hline & \multirow{2}{*}{$\begin{array}{l}\text { South } \\
\text { Africa }\end{array}$} & Poultry feeds & $\begin{array}{l}\text { UHPLC- } \\
\text { MS/MS }\end{array}$ & 19.40 & $100 \%(105)$ & 7125.0 & 1076.0 & 2019 & [33] \\
\hline & & Poultry feeds & $\begin{array}{l}\text { UHPLC- } \\
\text { MS/MS }\end{array}$ & 9.00 & $100 \%(62)$ & 2999.0 & 903.0 & 2012 & {$[6]$} \\
\hline
\end{tabular}


Table 2. Cont.

\begin{tabular}{|c|c|c|c|c|c|c|c|c|c|}
\hline \multicolumn{10}{|c|}{ Zearalenone } \\
\hline Mycotoxin & Country & Type of Sample & $\begin{array}{l}\text { Analytical } \\
\text { Technique }\end{array}$ & $\begin{array}{l}\text { LOD } \\
(\mu \mathrm{g} / \mathrm{kg})\end{array}$ & $\%$ Positive $(n)$ & $\operatorname{Max}(\mu \mathrm{g} / \mathrm{kg})$ & $\begin{array}{c}\text { Mean } \\
(\mu \mathrm{g} / \mathrm{kg})\end{array}$ & $\begin{array}{c}\text { Year of } \\
\text { Publication }\end{array}$ & Reference \\
\hline \multirow{10}{*}{ ZEN } & \multirow{2}{*}{ Botswana } & Poultry feed ingredients: peanut & $\begin{array}{l}\text { TLC and } \\
\text { HPLC-FLD }\end{array}$ & 20.00 & $5 \%(20)$ & 40.0 & 40.0 & \multirow{2}{*}{1998} & \multirow{2}{*}{ [20] } \\
\hline & & Poultry feeds & & & $25 \%(4)$ & 40.0 & 40.0 & & \\
\hline & Ethiopia & Poultry feed ingredients: maize & LC-MS/MS & 0.12 & $96 \%(100)$ & 1656.0 & 92.0 & 2018 & [29] \\
\hline & Kenya & $\begin{array}{l}\text { Poultry feed ingredients } \\
\text { Poultry feeds }\end{array}$ & LC-MS/MS & 0.20 & $\begin{array}{l}83 \%(24) \\
100 \%(27)\end{array}$ & $\begin{array}{l}910.4 \\
873.4\end{array}$ & $\begin{array}{c}71.3 \\
103.4\end{array}$ & 2020 & [10] \\
\hline & \multirow{4}{*}{ Nigeria } & poultry feeds & LC-MS/MS & & $83 \%(30)$ & 71.0 & 9.3 & \multirow{4}{*}{2018} & \multirow{4}{*}{ [8] } \\
\hline & & $\begin{array}{c}\text { Poultry feed ingredients: wheat } \\
\text { offal }\end{array}$ & & & $90 \%(10)$ & 67.0 & 19.0 & & \\
\hline & & $\begin{array}{l}\text { Poultry feed ingredients: peanut } \\
\text { cake }\end{array}$ & & & $18 \%(11)$ & 1.1 & 0.9 & & \\
\hline & & Poultry feed ingredients: maize & & & $65 \%(17)$ & 4.8 & 1.2 & & \\
\hline & \multirow{2}{*}{$\begin{array}{l}\text { South } \\
\text { Africa }\end{array}$} & Poultry feeds & $\begin{array}{l}\text { UHPLC- } \\
\text { MS/MS }\end{array}$ & 0.10 & $100 \%(105)$ & 428.9 & 71.2 & 2019 & [33] \\
\hline & & Poultry feed ingredients: maize & LC-MS/MS & 4.00 & $47 \%(308)$ & 6276.0 & & 2018 & [25] \\
\hline
\end{tabular}


Table 2. Cont.

\begin{tabular}{|c|c|c|c|c|c|c|c|c|c|}
\hline \multicolumn{10}{|c|}{ Ochratoxin A } \\
\hline Mycotoxin & Country & Type of Sample & $\begin{array}{l}\text { Analytical } \\
\text { Technique }\end{array}$ & $\begin{array}{l}\text { LOD } \\
(\mu \mathrm{g} / \mathrm{kg})\end{array}$ & $\%$ Positive $(n)$ & $\operatorname{Max}(\mu \mathrm{g} / \mathrm{kg})$ & $\begin{array}{c}\text { Mean } \\
(\mu \mathrm{g} / \mathrm{kg})\end{array}$ & $\begin{array}{c}\text { Year of } \\
\text { Publication }\end{array}$ & Reference \\
\hline \multirow{8}{*}{ OTA } & Benin & $\begin{array}{l}\text { Poultry feed ingredients: peanut } \\
\text { cake }\end{array}$ & LC-MS/MS & 0.10 & $33 \%(15)$ & 2.0 & & 2011 & [28] \\
\hline & Ethiopia & Poultry feed ingredients: maize & ELISA & 1.90 & $24 \%(150)$ & 186.5 & 8.2 & 2019 & [23] \\
\hline & Kenya & $\begin{array}{l}\text { Poultry feeds } \\
\text { Poultry feed ingredients }\end{array}$ & LC-MS/MS & 1.00 & $\begin{array}{l}19 \%(27) \\
8 \%(24)\end{array}$ & $\begin{array}{c}10.6 \\
1.1\end{array}$ & $\begin{array}{l}4.8 \\
0.6\end{array}$ & 2020 & [10] \\
\hline & \multirow{4}{*}{ Nigeria } & Poultry feeds & LC-MS/MS & 4.00 & $34 \%(58)$ & 26.0 & 10.0 & 2012 & [31] \\
\hline & & Poultry feeds & $\mathrm{LC}-\mathrm{MS} / \mathrm{MS}$ & & $27 \%(30)$ & 15.0 & 5.4 & \multirow[b]{3}{*}{2018} & \multirow[b]{3}{*}{ [8] } \\
\hline & & Poultry feed ingredients: maize & LC-MS/MS & & $12 \%(11)$ & 3.1 & 2.2 & & \\
\hline & & $\begin{array}{l}\text { Poultry feed ingredients: peanut } \\
\text { cake }\end{array}$ & & & $55 \%(11)$ & 127.0 & 35.0 & & \\
\hline & $\begin{array}{l}\text { South } \\
\text { Africa }\end{array}$ & Poultry feed ingredients: maize & LC-MS/MS & 0.20 & $7 \%(269)$ & 95.0 & & 2018 & [25] \\
\hline
\end{tabular}

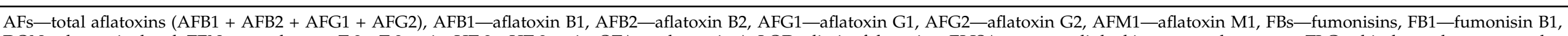

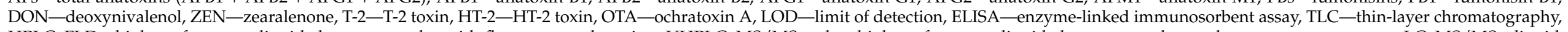

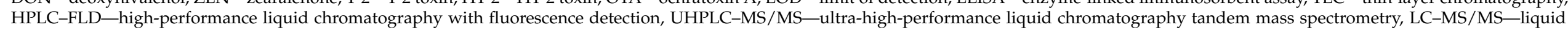
chromatography tandem mass spectrometry, LFIA—lateral flow immunochromatographic assay, $n$ —number of samples, EU regulatory limit for AFB1—20 $\mu \mathrm{g} / \mathrm{kg}$, mean—mean concentration of positives. 


\subsection{Aflatoxins}

Aflatoxins occurrences of between $64 \%$ and $100 \%$ have been reported in poultry feeds $[4,13,31,33]$. Levels above the EU regulatory limit of $20 \mu \mathrm{g} / \mathrm{kg}$ are reported mainly in countries in the tropical regions, including Nigeria [8,31], Ghana [4], Kenya [10], and Uganda [11]. This could be attributed to warm and humid tropical conditions coupled with poor agricultural practices that favor AFs production in these regions. On the other side, low occurrences and low levels (range: 0.3 to $0.7 \mu \mathrm{g} / \mathrm{kg}$ ) of AFs were reported in poultry feeds from South Africa [6,33], possibly due to variations in climatic conditions that affect the ecological niche of parent fungi and AFs accumulation. In feed ingredients, high occurrences and levels of AFs are mainly reported in oilseeds, such as peanut and sunflower, as well as their products. Over $60 \%$ of peanut from Benin [28], Cameroon [13], Ethiopia [22,35], and Nigeria $[8,32]$ were contaminated with AFs, and levels up to $11,900 \mu \mathrm{g} / \mathrm{kg}$ were reported. Similarly, sunflower cakes and seeds from Tanzania [26] and Kenya [34] had high AFs levels (max: $662.7 \mu \mathrm{g} / \mathrm{kg}$ ). Maize and maize products are also frequently contaminated with AFs. All maize samples from Malawi [24], Uganda [11], and Ethiopia [23] were contaminated with AFs at maximum levels of $150 \mu \mathrm{g} / \mathrm{kg}$. Lower incidences of below $50 \%$ were reported in maize samples from other SSA countries, although with levels as high as $567 \mu \mathrm{g} / \mathrm{kg}[8,27,29]$.

Besides AFB1, other AFs, including AFB2, AFG1, AFG2, and aflatoxin M1 (AFM1), have also been reported in poultry feeds and feed ingredients [8,10,33,34]. More than half of poultry feeds from Nigeria [8,31] and South Africa [33] were contaminated with AFB2 at levels up to $188 \mu \mathrm{g} / \mathrm{kg}$. Moreover, over $90 \%$ of peanut cake from Nigeria had AFB2 at a maximum level of $895 \mu \mathrm{g} / \mathrm{kg}$ [8]. In contrast, less than half of poultry feed and feed ingredients from Kenya [10] and other 13 African countries [25] were contaminated with AFB2. Aflatoxin G1 is the second most prevalent AFs in SSA besides AFB1 and has been reported in over $50 \%$ of poultry feeds [8,10,33]. The highest AFG1 levels of $235 \mu \mathrm{g} / \mathrm{kg}$ (mean: $45 \mu \mathrm{g} / \mathrm{kg}$ ) were reported in poultry feeds from Nigeria [31]. In feed ingredients, AFG1 occurred in over $80 \%$ of peanut meal from Nigeria at levels up to $568 \mu \mathrm{g} / \mathrm{kg}[8,32]$. Furthermore, levels up to $725 \mu \mathrm{g} / \mathrm{kg}$ were observed in maize from the same country [8]. Aflatoxin G2 has also been reported in over half of poultry feeds from South Africa [33] and feed and feed ingredients from Nigeria [34]. In contrast, less than half of poultry feeds from Kenya [10] and Nigeria [8,31] had detectable AFG2. In feed ingredients, the highest occurrences (55\%) and levels $(68 \mu \mathrm{g} / \mathrm{kg})$ of AFG2 were reported in peanut cake from Nigeria [8]. The presence of AFM1 in feeds and feed ingredients from SSA has been associated with the production of traces of AFM1 by most strains of aflatoxigenic Aspergilli [31]. Low occurrences of less than half of poultry feed samples from Kenya [10] and Nigeria [8,31] were reported at maximum levels of $41 \mu \mathrm{g} / \mathrm{kg}$. Interestingly, high occurrences of over $60 \%$ and levels up to $254 \mu \mathrm{g} / \mathrm{kg}$ were reported in peanut cake samples from Nigeria [8,32].

\subsection{Fumonisins}

Fumonisins are the second most common mycotoxins, and high occurrences of over $80 \%$ were reported in poultry feeds from South Africa [6,33], Kenya [10], Nigeria [8,31], and Ghana [4], although at levels below the EU guidance value of $20,000 \mu \mathrm{g} / \mathrm{kg}$ for FBs in poultry feeds. Low occurrences of below 50\% (range of means: 572 to $1210 \mu \mathrm{g} / \mathrm{kg}$ ) were however reported in poultry feeds from Botswana [20] and Rwanda [15]. The low occurrences and levels in the latter studies could be attributed to detection methods and sampling periods. In feed ingredients, over 70\% of samples from Kenya [10], Nigeria [8], and Ethiopia [23] were contaminated, with FBs at maximum levels of $11,831 \mu \mathrm{g} / \mathrm{kg}$. However, less than $40 \%$ of maize samples from Ethiopia [23,29] and Tanzania [27] had detectable FBs but at levels up to $62,000 \mu \mathrm{g} / \mathrm{kg}$. Unlike maize, peanuts and peanut products are not frequently contaminated with FBs, and less than half of samples from Nigeria $[8,32]$ and Benin [28] contained FBs (max: $910 \mu \mathrm{g} / \mathrm{kg}$ ). 


\subsection{Deoxynivalenol}

High occurrences of DON have also been reported in poultry feeds, although usually at levels below both South African and EU guidance values $[6,8,10,31,33]$. Almost all poultry feed samples from South Africa [6,33] and Kenya [10] were contaminated with DON at maximum levels of $1980 \mu \mathrm{g} / \mathrm{kg}$. However, DON was not a major contaminant of poultry feeds from Nigeria $[8,31]$. The low occurrences sometimes observed in samples from countries along the tropical regions can be due to DON most commonly being produced in temperate regions by pathogenic plant fungi, including Fusarium graminearum and $F$. culmorum [36]. Poultry feed ingredients such as maize and wheat are however frequently contaminated with DON [10,25,34], and levels up to $11,022 \mu \mathrm{g} / \mathrm{kg}$ (mean: $943 \mu \mathrm{g} / \mathrm{kg}$ ) were detected in wheat from South Africa [34]. Furthermore, DON was present in over half of feed ingredients from Kenya in the range of 22 to $996 \mu \mathrm{g} / \mathrm{kg}$ [10]. However, Worku et al. [23] reported DON in only $7 \%$ of maize samples from Ethiopia at concentration ranges of 270 to $1980 \mu \mathrm{g} / \mathrm{kg}$.

\subsection{Zearalenone}

Similar to DON and FBs, ZEN is reported to be a frequent contaminant of poultry feeds and was detected in over $50 \%$ of poultry feeds from Kenya [10], South Africa [6,33], and Nigeria [8,31]. Levels above the EU guidance value of $250 \mu \mathrm{g} / \mathrm{kg}$ were reported in poultry feeds from Kenya [10] and South Africa [6,33]. Ezekiel et al. [31], however, reported ZEN in only $22 \%$ of poultry feeds from Nigeria at mean concentrations of $45 \mu \mathrm{g} / \mathrm{kg}$. Poultry feed ingredients, especially maize, are also reported to be frequently contaminated with ZEN [10,25,29], and levels up to $6276 \mu \mathrm{g} / \mathrm{kg}$ were observed in maize from South Africa [25], while a small study found levels up to $165,000 \mu \mathrm{g} / \mathrm{kg}$ [37]. However, low occurrences of ZEN in less than half of maize from other African countries [20,25] and peanut cake samples from Nigeria [8] were reported.

\subsection{T-2 and HT-2 Toxins}

There is limited information on occurrences of T-2 and HT- 2 toxins in feed and feed ingredients from SSA, and the few studies indicate that they are not major contaminants in this region. Occurrences of both T-2 and HT-2 toxins were reported in $4 \%$ of poultry feeds from Kenya at mean levels of 13.8 and $5.2 \mu \mathrm{g} / \mathrm{kg}$, respectively [10]. However, Mokubedi et al. [33] reported occurrences of both T-2 and HT-2 toxins in all tested poultry feeds from South Africa at mean concentrations of 3.1 and $1.9 \mu \mathrm{g} / \mathrm{kg}$, respectively. In feed ingredients, $\mathrm{T}-2$ toxin occurred in less than $5 \%$ of maize from different countries in Africa at maximum levels of $80 \mu \mathrm{g} / \mathrm{kg}$ [25].

\subsection{Ochratoxin A}

Similar to T-2 and HT-2 toxins, OTA is not an important contaminant of poultry feeds in the region, and low occurrences of less than $34 \%$ (range of means: 4.8 to $10.0 \mu \mathrm{g} / \mathrm{kg}$ ) were reported in poultry feeds from Nigeria [8,31] and Kenya [10]. In the latter studies, low levels of OTA were found together with high occurrences and levels of AFs, which could be attributed to OTA being produced by the same Aspergillus spp. fungi that produce AFs. In feed ingredients, low occurrences and levels were further reported in samples from Kenya [10], Nigeria [8,34], and South Africa [23]. Gruber-Dorninger et al. [25], however, reported OTA at levels up to $694 \mu \mathrm{g} / \mathrm{kg}$ in maize samples from different African countries. Similar to maize, peanut and peanut products are reported to be susceptible to infestation by Aspergillus spp. fungi and thus prone to contaminations by OTA. Over half of peanut cake samples from Nigeria had OTA at maximum levels of $127 \mu \mathrm{g} / \mathrm{kg}$ [8]. In contrary results, OTA was detected in less than $33 \%$ of peanut cake samples from Benin [28] and Nigeria [32]. 


\subsection{Co-Occurrence of Mycotoxins}

Co-occurrence of mycotoxin in poultry feeds has been observed in field conditions since the different feed ingredients are colonized by more than one fungus and because most fungi can produce several mycotoxins simultaneously [12]. Contamination of poultry feeds and feed ingredients by more than one mycotoxin is reported in various studies $[4,8,10,23,25,31]$; however, there is likely underestimation since not all known mycotoxins are tested, and in some studies, the methods employed are not capable of detecting all mycotoxins of interest. Aflatoxins and FBs are the most frequently reported co-occuring mycotoxin combination and were recently found to co-occur in all tested poultry feeds from Ghana [4] This co-occurrence was also the most common in poultry feeds and feed ingredients in other studies $[8,10,15,23,25]$. Besides co-occurring with FBs, AFs were recently reported to co-occur with ZEN in all feed and feed ingredients from Kenya, whereas AFs and DON co-occurred in over $80 \%$ of the samples [10]. Furthermore, co-occurrences of AFs with FBs, ZEN, and DON were reported in over half of poultry feeds from South Africa [33]. In the latter study, FBs, ZEN, and DON co-occurred in $42 \%$ of the samples. Njobeh et al. [6] also reported co-occurrence of FBs, DON, and ZEN in over $60 \%$ of feeds from South Africa, whereas FBs, DON, ZEN, and AFs co-occurred in $26 \%$ of the samples. Co-occurrence of five mycotoxins, including FBs, DON, ZEN, AFs, and OTA, in about $0.1 \%$ of the samples was also reported in the latter study. Interestingly, Olopade et al. [38] recently reported that DON and ZEN did not co-occur in maize, sorghum, and millet samples from Nigeria. Co-occurrences of mycotoxins can lead to toxicological interactions, thereby making some mycotoxins harmful even at low levels due to synergistic or additive effects [16].

\section{Mycotoxins in Poultry Food Products from Surveys Conducted in SSA}

Occurrences of mycotoxin residues in biological samples, especially animal source foods, were used to evaluate mycotoxin exposure in animals and assess the risk to human consumers [39]. Although various studies indicate that chicken eggs and meat are only minor contributors to human dietary mycotoxin exposure [40,41], chronic exposure to these low levels could have a negative impact on the health of human consumers [42,43]. Iqbal et al. [44] reported the highest total AFs concentration of $8 \mu \mathrm{g} / \mathrm{kg}$ in livers of chickens compared with other organs, because the liver is the primary target organ of AFs. Using ELISA methods, AFB1 was detected in 39\% of liver samples (mean level: $1.7 \mu \mathrm{g} / \mathrm{kg}$ ) and about $14 \%$ of gizzard samples (mean level: $1.1 \mu \mathrm{g} / \mathrm{kg}$ ) in Mozambique [42]. Mycotoxin residues have also been detected in chicken eggs, although low transmission rates of below $1 \%$ from feed to eggs are often reported [40,45]. Using HPLC methods, Tchana et al. [46] reported total AFs in about $45 \%$ of egg samples from Cameroon at levels up to $7.6 \mu \mathrm{g} / \mathrm{kg}$ (mean: $0.8 \mu \mathrm{g} / \mathrm{kg}$ ).

\section{Aflatoxicosis Outbreaks in Poultry in Africa}

Aflatoxicosis outbreaks linked to consumption of contaminated feed and feed ingredients have been reported to cause death of a large number of poultry in Kenya and Morocco [47]. Local or imported feed and feed ingredients (especially maize and groundnuts) have been associated with three aflatoxicosis outbreaks in different parts of Kenya [47,48]. During the aflatoxicosis outbreaks, large numbers of poultry were affected, with death being the major effect reported. In Morocco, consumption of feed contaminated with AFs up to levels of $5625 \mu \mathrm{g} / \mathrm{kg}$ resulted in aflatoxicosis outbreak that affected a large number of poultry [49]. In the latter study, death of poultry was again the reported effect.

\section{Toxicological Impact of Major Mycotoxins on Experimental Broilers and Layer Chickens}

Consumption of mycotoxin-contaminated feeds has been reported to cause poor health and performance of chickens as well as mortalities (Table 3); however, there are limited data in the SSA context. Apart from a few studies, mostly conducted in Nigeria [50,51], the impacts are reported from trials conducted in other countries. Effects of a mycotoxin 
on an animal depend on the mycotoxin type, level and duration of exposure, age, and specie of the animal. Acute toxicity is caused by intake of high doses of mycotoxins and is characterized by death and well-described clinical signs [37]. Aflatoxins are reported to cause reduced bird performance, lower immunity, organ damage, and reduced egg production [52-55]. On the other hand, toxicity due to FBs has been linked to disruption of the biosynthesis of sphingosine (So) and sphinganine (Sa) due to structural similarity between these sphingolipids and FBs backbone [56-58]. Furthermore, FBs have been reported to cause nephrotoxicity, diarrhea, reduced body weight gain, and organ damage in chickens [59-61]. Trichothecenes, including DON, are mainly reported to exhibit toxicity through inhibition of protein synthesis and bonding to sulfhydryl groups at the subcellular, cellular, and organic system levels $[16,45,58]$. Several studies have indicated that animals, including poultry, are naturally exposed to high doses of trichothecenes compared with humans, with reduced weight and immunosuppression being observed in chronic exposures, whereas vomiting, nausea, irritation, and lesions are reported in acute exposures $[60,62,63]$. Zearalenone is reported to have estrogen-mimicking effects, and its toxicity has been associated with damaged reproductive organs [64,65]. Toxicity due to OTA has been shown to be through generation of DNA adducts that cause impairment of protein synthesis, increased oxidative stress, and inhibition of mitochondrial function [66,67]. Subacute levels of OTA are reported to be nephrotoxic, immunosuppressive, and teratogenic in animals $[67,68]$.

Table 3. Effects of major mycotoxins on layer and broiler chickens' health and productivity and presence of residues.

\begin{tabular}{|c|c|c|c|c|c|c|}
\hline Mycotoxin & $\begin{array}{l}\text { Dosage (mg/kg } \\
\text { Diet) }\end{array}$ & Species & $\begin{array}{l}\text { Age at Start of the } \\
\text { Trial (Days) }\end{array}$ & $\begin{array}{c}\text { Period of } \\
\text { Exposure (Days) }\end{array}$ & Effects Observed & Reference \\
\hline AFs & 0.02 & Broilers & 1 & 35 & $\begin{array}{l}\text { Increased liver and kidney weights } \\
\text { Decreased serum albumin, ALP, and ALT }\end{array}$ & [69] \\
\hline \multirow{6}{*}{ AFB1 } & 0.05 & Broilers & 3 & 42 & $\begin{array}{c}\text { Decreased BW gain and FI } \\
\text { Decreased serum g-GGT, AST, and ALT } \\
\text { Residues of AFB1 and AFM1 in livers }\end{array}$ & \multirow[b]{2}{*}{ [70] } \\
\hline & 0.1 & Broilers & 3 & 42 & $\begin{array}{c}\text { Decreased BW gain and FI } \\
\text { Decreased serum g-GGT, AST, and ALT } \\
\text { Residues of AFB1 and AFM1 in livers and } \\
\text { muscle }\end{array}$ & \\
\hline & 0.2 & Broilers & 8 & 33 & $\begin{array}{c}\text { Decreased BW and BW gain } \\
\text { Decreased mean antibody titers against vaccine } \\
\text { for Newcastle disease } \\
\text { Hepatic histopathology changes }\end{array}$ & [71] \\
\hline & 0.5 & Broilers & 1 & 56 & $\begin{array}{c}\text { Decreased BW and BW gain } \\
\text { Increased FCR } \\
\text { Increased mortality } \\
\text { Increased liver, spleen, and kidney weights }\end{array}$ & [51] \\
\hline & 2 & Broilers & 1 & 21 & $\begin{array}{c}\text { Decreased BW gain and FI } \\
\text { Decreased serum Prot, Alb, Ca, and Glu } \\
\text { Increased liver weights } \\
\text { Hepatic histopathology changes }\end{array}$ & [72] \\
\hline & 2.5 & Broilers & 23 & 27 & $\begin{array}{c}\text { Decreased BW gain } \\
\text { Decreased serum Prot, Alb, and Glob } \\
\text { Increased liver weights } \\
\text { Hepatic histopathology changes }\end{array}$ & [73] \\
\hline AFs & 3 & Broilers & 1 & 42 & $\begin{array}{l}\text { Decreased BW and BW gain } \\
\text { Decreased serum Prot, } \mathrm{Ca}, \mathrm{K} \text {, and Chol } \\
\text { Increased liver weights }\end{array}$ & [74] \\
\hline AFB1 & 5 & Broilers & 30 & 22 & $\begin{array}{l}\text { Decreased BW gain } \\
\text { Decreased serum Prot, Alb, and Glob } \\
\text { Increased liver weights } \\
\text { Hepatic histopathology changes }\end{array}$ & [75] \\
\hline \multirow{3}{*}{ AFs } & 5 & Broilers & 1 & 21 & $\begin{array}{l}\text { Decreased BW gain and FI } \\
\text { Decreased hepatic vitamin A levels } \\
\text { Increased liver weights }\end{array}$ & [76] \\
\hline & 0.05 & Layers & 210 & 60 & $\begin{array}{c}\text { Decreased FI } \\
\text { Residues of AFB1 in eggs }\end{array}$ & \multirow{2}{*}{ [77] } \\
\hline & 0.10 & Layers & 210 & 60 & $\begin{array}{c}\text { Decreased FI } \\
\text { Residues of AFB1 in eggs }\end{array}$ & \\
\hline
\end{tabular}


Table 3. Cont.

\begin{tabular}{|c|c|c|c|c|c|c|}
\hline Mycotoxin & $\begin{array}{l}\text { Dosage (mg/kg } \\
\text { Diet) }\end{array}$ & Species & $\begin{array}{l}\text { Age at Start of the } \\
\text { Trial (Days) }\end{array}$ & $\begin{array}{c}\text { Period of } \\
\text { Exposure (Days) }\end{array}$ & Effects Observed & Reference \\
\hline AFB1 & 2.5 & Layers & 308 & 28 & $\begin{array}{c}\text { Decreased egg quality } \\
\text { Residues of AFB1 in livers }\end{array}$ & [78] \\
\hline AFs & 5 & Layers & 189 & 32 & $\begin{array}{c}\text { Decreased egg production } \\
\text { Decreased serum trig, Ca, P, AST, and ALT } \\
\text { Increased liver weights } \\
\text { Hepatic histopathology changes }\end{array}$ & [52] \\
\hline \multirow[t]{2}{*}{ DON } & 15 & Broilers & 1 & 42 & $\begin{array}{c}\text { Decreased BW gain } \\
\text { Increased FCR } \\
\text { Increased weight of thymus and gizzard } \\
\text { Decreased weight of colon } \\
\text { Decreased cholesterol } \\
\text { Changes in small intestine morphometry }\end{array}$ & [79] \\
\hline & 19.3 & Broilers & 6 & 8 & $\begin{array}{l}\text { Decreased villi height } \\
\text { Increased crypt depth } \\
\text { Decreased intestinal health }\end{array}$ & [80] \\
\hline \multirow{4}{*}{ FB1 } & 20 & Broiler & 1 & 35 & Increased Sa/So and Sa & [59] \\
\hline & 50 & Broilers & 8 & 33 & $\begin{array}{c}\text { Decreased BW and BW gain } \\
\text { Decreased mean antibody titers for vaccine } \\
\text { against Newcastle disease } \\
\text { Hepatic histopathology changes }\end{array}$ & [71] \\
\hline & 100 & Broiler & 1 & 28 & $\begin{array}{c}\text { Decreased FI and BW } \\
\text { Increased FCR } \\
\text { Increased liver weights } \\
\text { Increased Sa/So } \\
\text { Increased serum Prot, Alb, Chol, Trig, Ca, ALT, } \\
\text { and AST } \\
\text { Decreased villus height and villus-to-crypt } \\
\text { ratioHepatic histopathology changes }\end{array}$ & [81] \\
\hline & 200 & Broilers & 8 & 33 & $\begin{array}{c}\text { Decreased BW and BW gain } \\
\text { Decreased mean antibody titers against vaccine } \\
\text { for Newcastle disease } \\
\text { Increased liver weights } \\
\text { Hepatic histopathology changes }\end{array}$ & [71] \\
\hline ZEN & 2 & Broilers & 1 & 42 & $\begin{array}{c}\text { Decreased BW gain } \\
\text { Increased FCR } \\
\text { Increased liver weight } \\
\text { Increased serum AST and ALT levels } \\
\text { Residues of ZEN in liver and kidney }\end{array}$ & [65] \\
\hline \multirow{5}{*}{ OTA } & 0.05 & Broilers & 7 & 28 & $\begin{array}{c}\text { Decreased BW gain } \\
\text { Decreased leukocyte and lymphocyte count } \\
\text { Intestinal mucosa architecture alterations }\end{array}$ & [82] \\
\hline & 0.1 & Broilers & 1 & 42 & $\begin{array}{c}\text { Decreased BW } \\
\text { Increased heart weight } \\
\text { Residues of OTA in liver }\end{array}$ & [83] \\
\hline & 0.4 or 0.8 & Broilers & 1 & 35 & $\begin{array}{c}\text { Decreased BW and FI } \\
\text { Decreased thyroxine concentration } \\
\text { Decreased WBC, humoral immune response, } \\
\text { and cell-mediated immunity } \\
\text { Increased gizzard weight } \\
\text { Increased mortality } \\
\text { Anemia }\end{array}$ & [84] \\
\hline & 2.5 & Broilers & 1 & 21 & $\begin{array}{c}\text { Decreased BW gain } \\
\text { Decreased serum Prot, Alb, and Chol } \\
\text { Increased serum uric acid and Trig } \\
\text { Increased weight of kidney }\end{array}$ & [85] \\
\hline & 5 & Layers & 14 & 365 & $\begin{array}{c}\text { Decreased egg weights } \\
\text { Decreased egg production } \\
\text { Delay of the beginning of the laying period }\end{array}$ & [86] \\
\hline $\mathrm{T}-2$ & 2 & Broilers & 1 & 21 & $\begin{array}{l}\text { Decreased spleen weight and size } \\
\text { Decreased CD4+/CD8+ } \\
\text { Increased apoptotic splenocytes } \\
\text { Lesions in spleen }\end{array}$ & [87] \\
\hline
\end{tabular}

AFs—sum of aflatoxin B1, aflatoxin B2, aflatoxin G1, and aflatoxin G2; AFB1—aflatoxin B1; AFM1—aflatoxin M1; FB1—fumonisin B1; DON—deoxynivalenol; ZEN—zearalenone; T-2-T-2 toxin; OTA—ochratoxin A; BW—body weight; FI—feed intake; FCR—feed conversion ratio; Prot-protein; Alb—albumin; Glob—globulin; Glu—glucose; Chol—cholesterol; Trig—triglyceride; Ca—calcium; K—potassium; $\mathrm{P}$-phosphorus; WBC—white blood cells; Sa—sphinganine; Sa/So—sphinganine-to-sphingosine ratio; AST—aspartate aminotransferase; ALT—alanine aminotransferase; ALP—alkaline phosphatase; g-GGT—gamma glutamyl transferase. 


\subsection{Immunosuppression, Susceptibility to Diseases, and Mortality}

The immunosuppressive effects of mycotoxins have been shown to cause reduced disease resistance, reduced drug efficacy, and vaccine failures, making the animal more susceptible to diseases and increasing mortalities $[19,55,60,88]$. Farmers, therefore, incur hidden costs related to the treatment of diseased animals and economic losses due to mortalities. In Nigeria, the highest mortality was reported in broilers fed $500 \mu \mathrm{g}$ AFB1/kg feed [51]. The levels of AFB1 used in the latter study are practically relevant since levels up to $1067 \mu \mathrm{g} / \mathrm{kg}$ were reported in poultry feeds from the same country [8], implying that the poultry sector is at risk. Other studies on the effects on poultry in SSA are lacking, but there are data from trials worldwide that are also relevant for the SSA context. Naseem et al. [89] reported the highest mortality in young layers fed $200 \mu \mathrm{g}$ AFB1/ $\mathrm{kg}$ feed and challenged with fowl adenovirus 4 . Similarly in another study, the highest mortality was observed in broiler chickens fed AFB1 (750 or $1500 \mu \mathrm{g} / \mathrm{kg}$ feed) and challenged with Clostridium perfringens pathogen [90]. For OTA, the highest mortality was reported in broiler chickens fed $1000 \mu \mathrm{g}$ OTA/ $\mathrm{kg}$ feed and challenged with coccidia [91], and mortality of about $13 \%$ was observed in young broilers fed $800 \mu \mathrm{g}$ OTA $/ \mathrm{kg}$ feed [84]. Mycotoxins, even at subclinical levels, lead to immunological and metabolic disturbances, thereby enhancing diseases in chickens. Enhanced coccidiosis was observed in broilers fed $1000 \mu \mathrm{g}$ OTA $/ \mathrm{kg}$ diet and challenged with coccidia [91]. Moreover, mycotoxins such as DON and FBs are poorly absorbed and remain in the gastrointestinal tract, impairing highly dividing intestinal cells and providing growth substrates for the colonization of the digestive system by pathogens [60,61]. Increased necrotic enteritis was reported in chickens fed FBs-contaminated diets and challenged with C. perfringens [60]. Additionally, feeding subclinical doses of Fusarium mycotoxins, including FBs, DON, 15-acetyl DON, and ZEN, enhanced coccidiosis or retarded recovery in coccidia-challenged broiler chickens [61,92].

Reduced immune responses characterized by reduced antibody titers against vaccines, such as infectious bronchitis vaccine (IBV) and Newcastle disease vaccine (NDV), have been associated with immunosuppressive effects of some mycotoxins [71,93]. Immunotoxic doses of mycotoxins have been observed to be less than the doses required to elicit a reduction in bird performance, and levels such as those reported in poultry feeds from SSA can be immunotoxic. In a feeding trial, immunosuppressive effects of AFB1 (50 or $200 \mu \mathrm{g} / \mathrm{kg}$ feed) or FB1 (50,000 or 200,000 $\mu \mathrm{g} / \mathrm{kg}$ ), individually or combined, were reported to reduce antibody titers against NDV in broiler chickens [71]. Additionally, dose-dependent decreases in antibody titers against IBV in broiler chickens fed low to moderate DON levels (1680 to $12,209 \mu \mathrm{g} / \mathrm{kg}$ feed) were associated with immunosuppression [94]. Kamalavenkatesh et al. [93] also demonstrated that reduced hemagglutination inhibition titers to NDV in broilers fed CPA $(10,000 \mu \mathrm{g} / \mathrm{kg}$ feed $)$ or T-2 $(1000 \mu \mathrm{g} / \mathrm{kg}$ feed), alone or in combination, were a result of the immunosuppressive effects of the two toxins. Feeding chickens OTA at levels of 150 to $1000 \mu \mathrm{g} / \mathrm{kg}$ feed resulted in immunosuppressive effects characterized by reduced antibody titers against sheep red blood cells [67,84]. Additionally, decreases in leukocyte counts are also indicative of damaged lymphoid tissues and impaired immune function. Feeding OTA at levels of 20 or $50 \mu \mathrm{g} / \mathrm{kg}$ body weight per day was reported to reduce leukocyte counts in young broiler chickens [82], and Li

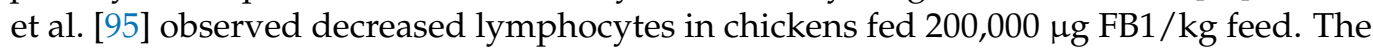
immunosuppressive effects of CPA $(10,000 \mu \mathrm{g} / \mathrm{kg}$ feed) or T-2 (1000 $\mu \mathrm{g} / \mathrm{kg}$ feed), alone or in combination, were reported to cause decreases in lymphocytes of broiler chickens [93]. Chen et al. [87] demonstrated that T-2 toxin (500 to $2000 \mu \mathrm{g} / \mathrm{kg}$ feed) impaired splenic immune function and was manifested through increased apoptotic splenocytes and reduced CD4+/CD8+ T cells. Aflatoxicosis has also been linked to Vitamin A deficiencies in poultry causing reduced immune responses and enhanced susceptibility to diseases, and in a feeding trial, hepatic vitamin A levels were reduced in young broiler chickens fed high AF levels (5000 $\mu \mathrm{g} / \mathrm{kg}$ feed) [76]. 


\subsection{Impaired Growth}

Retarded growth resulting from mycotoxin-contaminated feeds results in poultry not attaining the required weights at the required time and thus economic losses as farmers use more feed and time to attain the required weights [88]. In Nigeria, broilers fed diets contaminated with AFB1 at levels of $34 \mu \mathrm{g} / \mathrm{kg}$ [50] or $500 \mu \mathrm{g} / \mathrm{kg}$ [51] had reduced feed intake and body weight (BW) gain compared with birds fed AFs-free diets. Decreased BW and BW gain were reported in broilers fed AFs at levels of 50 to $200 \mu \mathrm{g} / \mathrm{kg}[64,71,96]$. The levels of AFs used in the previous studies have been reported in poultry feeds and feed ingredients from SSA, implying that AFs pose a concern to poultry production in the region. High AFs levels of between 2000 and $5000 \mu \mathrm{g} / \mathrm{kg}$ feed caused reduced growth rates in broiler chickens $[69,72,73,75,97]$, with a decrease of about $35 \%$ being observed in one of the studies [98]. Diets contaminated with FBs are also reported to cause poor performance through feed refusal and diarrhea, and in experimental studies, FBs at levels of $10,000 \mu \mathrm{g} / \mathrm{kg}$ feed [99] or 200,000 $\mu \mathrm{g} / \mathrm{kg}$ feed [71] resulted in decreased broiler chicken BW and BW gain and increased feed conversion ratio (FCR). Moreover, toxicity due to DON has been associated with reduced feed intake and hence poor growth rate. Feeding DON-contaminated diets at low to moderate levels (1680 to $12,209 \mu \mathrm{g} / \mathrm{kg}$ feed) resulted in decreased BW and BW gain of broiler chickens $[62,94,100]$. While these studies have not been conducted in SSA, similar levels of DON have been reported in poultry feed and feed ingredients from SSA, indicating that DON can have a negative impact on poultry production in the region too. In addition, the toxicity of OTA has been reported to cause impairment of the gastrointestinal tract in chickens, resulting in poor nutritional absorption and hence poor growth rate [68]. Reduced BW and BW gain were observed in broiler chickens fed OTA at levels of 20 or $50 \mu \mathrm{g} / \mathrm{kg}$ BW [82,101] or 100 to $800 \mu \mathrm{g} / \mathrm{kg}$ feed [83,84], with the difference between the FCR of the group fed control and OTA-contaminated diets increasing by about $19 \%$ after 13 days of feeding in one of the studies [101]. Feeding ZEN-contaminated diets at levels of $2000 \mu \mathrm{g} / \mathrm{kg}$ feed was reported to reduce BW gain and increase FCR in broiler chickens [65]. Furthermore, toxicity due to T-2 (4500 or 13,500 $\mu \mathrm{g} / \mathrm{kg}$ feed) was observed to decrease the feed intake and BW gain of broiler chickens [102], although the levels of T-2 used in the study were high and have not been reported in poultry feeds from SSA.

\subsection{Changes in Organ Weight}

Several in vitro and ex vivo studies have indicated that consumption of feeds contaminated with mycotoxins can lead to damage of various organs in chickens manifested through increased or decreased weights. In Nigeria, increased weights of the liver, spleen, and kidneys were reported in broilers fed diets contaminated with $500 \mu \mathrm{g}$ AFB1/kg [51]. Furthermore, increased weights of the liver, heart, and kidney were observed in broilers fed AFs at EU-tolerated levels (20 $\mu \mathrm{g} / \mathrm{kg}$ feed) [103], moderate levels (200 $\mu \mathrm{g} / \mathrm{kg}$ feed) [71], or high levels (2000 $\mu \mathrm{g} / \mathrm{kg}$ feed) [69]. Additionally, increased relative weights of the liver and heart were reported in broilers due to toxicity of FBs $(50,000$ or $200,000 \mu \mathrm{g} / \mathrm{kg}$ feed) [71]. Toxicity due to OTA at levels of 100 and $2500 \mu \mathrm{g} / \mathrm{kg}$ feed also led to increased weights of the hearts [83] and kidneys [85] of broiler chickens, respectively. In contrary reports, reduced liver weights were observed in broiler chickens fed DON at low to moderate levels (2500 to 10,000 $\mu \mathrm{g} / \mathrm{kg}$ feed) [100] or ZEN at levels of $2000 \mu \mathrm{g} / \mathrm{kg}$ [65]. Deoxynivalenol toxicity has also been reported to cause damages to immune organs, such as the spleen and thymus, and alter intestinal morphology [36]. Recently, increased weights of the thymus and spleen and decreased weights of the colon were reported in broiler chickens fed DON at levels between $5000 \mu \mathrm{g} / \mathrm{kg}$ feed and 15,000 $\mu \mathrm{g} / \mathrm{kg}$ feed [62,79]. Additionally, altered immune systems were reported to be linked to decreases in the size and relative weight of the spleen in broiler chickens fed T-2 (500 to $2000 \mu \mathrm{g} / \mathrm{kg}$ feed) [87] and decreased thymus weight in broilers fed OTA (400 or $800 \mu \mathrm{g} / \mathrm{kg}$ feed) [84]. 


\subsection{Changes in Blood Biochemical Parameters}

Changes in blood parameters are reported to be more sensitive than other parameters, such as production performance, and thus can act as indicators of mycotoxicosis in advance of other symptoms [104]. Blood parameter changes caused by impaired protein synthesis have been shown to be marked by decreased blood total protein, globulin, and albumin levels and have been linked to mycotoxicosis. Reduced plasma protein was observed in broiler chickens fed $200 \mu \mathrm{g}$ AFB1/ kg feed [104], and decreased serum total protein, albumin, and globulin were observed in broiler chickens fed high AFs levels (2000 to $5000 \mu \mathrm{gg} / \mathrm{kg}$ feed) $[72,73,75]$. Toxicity due to OTA at levels of $567 \mu \mathrm{g} / \mathrm{kg}$ feed caused a reduction in plasma proteins, albumin, and globulins [66], and DON at levels of 10,000 $\mu \mathrm{g} / \mathrm{kg}$ diets was associated with inhibition of hepatic metabolisms and transport, resulting in reduced serum total protein in broiler chickens [105]. However, increased serum protein was observed in broiler chickens exposed to low or moderate DON levels (1680 or 12,209 $\mu \mathrm{g} / \mathrm{kg}$ feed) [94]. Similarly, increased total plasma protein and albumin were observed in broiler chickens due to FBs toxicity $(100,000$ or $200,000 \mu \mathrm{g} / \mathrm{kg}$ feed) [81]. Variations in the changes of biochemical parameters observed in the different studies can be attributed to age, sex, metabolic state, breed, and levels of mycotoxins and duration of exposure. Mycotoxicosis has also been associated with disruption of cholesterol biosynthesis, and in feeding trials, decreased cholesterol levels up to $24 \%$ were observed in broiler chickens fed high AFs levels (3000 to $5000 \mu \mathrm{g} / \mathrm{kg}$ feeds) [74,106]. In contrast, increased cholesterol levels were observed in broiler chickens fed FBs at levels of 100,000 or $400,000 \mu \mathrm{g} / \mathrm{kg}$ feed [81]. Disruption of renal functions due to aflatoxicosis was reported to result in decreased serum calcium levels up to $21 \%$ in broilers fed 3000 to $4000 \mu \mathrm{g} \mathrm{AFs} / \mathrm{kg}$ feed [74,98] and layers fed 2500 or $5000 \mu \mathrm{g} \mathrm{AFs} / \mathrm{kg}$ [52]. However, increased serum calcium levels were observed in broilers fed FBs at levels of 100,000 to 400,000 $\mu \mathrm{g} / \mathrm{kg}$ feed [81]. Interferences with lipid metabolisms due to DON $(10,000 \mu \mathrm{g} / \mathrm{kg}$ diet) toxicity resulted in reduced plasma triglycerides in broiler chicks [105]. In the latter study, a reduction in plasma uric acid levels was also observed. Gentles et al. [85], however, reported increased serum uric acid levels in young broilers fed OTA at levels of $2500 \mu \mathrm{g} / \mathrm{kg}$. Various studies conducted in SSA indicated that OTA was not a common contaminant of poultry feed and feed ingredients, and the levels used in the latter study are considerably high and have not been reported in the field.

Mycotoxicosis causes hepatocyte degeneration and subsequent leakage of certain enzymes, such as aspartate aminotransferase (AST), alanine aminotransferase (ALT), lactic acid dehydrogenase (LDH), and gamma glutamyl transferase (GGT), into the blood [104]. However, some enzymes are synthesized not exclusively in the liver but also in the heart, kidney, brain, and skeletal muscle [70]. In experimental feeding trials, increased serum levels of AST [70,104], ALT, and GGT [70] were observed in broiler chickens fed 50 to $200 \mu \mathrm{g} \mathrm{AFB} 1 / \mathrm{kg}$ of feed. These latter studies indicate that exposure to AFs levels such as those reported in poultry feeds in tropical regions of SSA can cause liver damages. Additionally, increases in serum ALT, LDH, and GGT levels were reported in broiler [74] and layer [52] chickens fed high AFs levels (2500 to $5000 \mu \mathrm{g} / \mathrm{kg}$ feed). Moreover, increases in serum AST levels in broiler chickens were linked to toxicity of FBs $(200,000 \mu \mathrm{g} / \mathrm{kg}$ feed) [104] or ZEN (2000 $\mu \mathrm{g} / \mathrm{kg}$ feed) [65]. Changes in creatine kinase activity has been linked to damages in tissues, and reductions in creatine kinase activities were observed in broiler chickens fed DON at levels of $5000 \mu \mathrm{g} / \mathrm{kg}$ feed [79]. Damaged sphingolipids due to FBs at EU-tolerated limits of $20,000 \mu \mathrm{g} / \mathrm{kg}$ feed were reported to cause increased serum-free Sa levels and Sa-to-So ratios in broiler chickens [59-61].

\subsection{Gross or Histopathological Changes}

Pathological changes such as lesions have been used as indicators of exposure to mycotoxins. Liver histopathological changes were observed in broilers fed AFB1 at EU limits of $20 \mu \mathrm{g} / \mathrm{kg}$ [103] or levels of 50 to $200 \mu \mathrm{g} / \mathrm{kg}$ diets [71,96]. Moderate to high AFs levels (750 to $5000 \mu \mathrm{g} / \mathrm{kg}$ feed) were also shown to cause mild to moderate liver histopathological changes in broiler $[69,72,73,90,98]$ and layer chickens [52]. Recently, high 
liver and intestinal lesion scores were observed in broiler chickens fed DON $(19,300 \mu \mathrm{g} / \mathrm{kg}$ feed) [80], and feeding FBs (50,000 or 200,000 $\mu \mathrm{g} / \mathrm{kg}$ feed) also caused liver histological changes in broiler chickens [70]. Additionally, intestinal pathogenicity of OTA (20 or $50 \mu \mathrm{g}$ OTA $/ \mathrm{kg}$ body weight per day) was associated with changes in the intestinal morphology of broiler chickens characterized by lesions [82,101]. Furthermore, immunosuppressive effects of $2000 \mu \mathrm{g}$ OTA/ $\mathrm{kg}$ feed were linked to histopathological changes observed in the thymus and bursa of broiler chickens [67]. Chen et al. [87] reported lesions in spleens of broiler chickens fed T-2 (500 to $2000 \mu \mathrm{g} / \mathrm{kg}$ feed). Recently, histopathological changes were observed in renal cortical cells of broiler and layer chickens fed citrinin (CIT) at levels of 100 to $3500 \mu \mathrm{g} / \mathrm{kg}$ feed [40]. Toxicity due to DON (5000 to $15,000 \mu \mathrm{g} / \mathrm{kg}$ feed) $[63,80,107]$ or FBs at levels recommended by EU [60] was also reported to cause intestinal damages characterized by reduced villus height and villus height and crypt depth ratio.

\subsection{Reduced Egg Production and Egg Quality}

Mycotoxicosis has been reported to be a great concern in commercial layer production, compromising egg production and egg quality [77,108]. Diets contaminated with mycotoxins are reported to cause liver malfunctioning, thus negatively affecting liver synthesis and transport of yolk precursors [78]. Reduced egg production [52] and poor egg quality $[78,109]$ were reported in chickens fed a 2500 to $5000 \mu \mathrm{g}$ AFs $/ \mathrm{kg}$ diet. Furthermore, feeding AFs and DON both at levels of $2000 \mu \mathrm{g} / \mathrm{kg}$ feed resulted in decreased egg production and egg weight [110]. Stoev et al. [86] also observed decreased egg production and egg weight, as well as delay in the beginning of the laying period for layer hens fed OTA at levels of 1000 or $5000 \mu \mathrm{g} / \mathrm{kg}$ feed. Furthermore, Devegowda and Ravikiran [108] in their review reported that major mycotoxins, including AFs, ZEN, OTA, FB1, CIT, cyclopiazonic acid (CPA), and patulin, caused poor quality of eggs that are rejected as table eggs or hatching eggs, leading to significant losses in layer production.

\subsection{Impact of Co-Occurrences of Mycotoxins on Broiler and Layer Chickens}

Most toxicological studies report the toxic effects of only one mycotoxin, yet cooccurrences of mycotoxins are frequently observed in poultry feeds from SSA $[8,10,33]$. Enhanced toxicities due to the synergistic or additive effects of multiple contaminations compared with single mycotoxin contamination have been reported. The additive toxic effects of AFB1 (200 $\mu \mathrm{g} / \mathrm{kg}$ feed) and FB1 (200,000 $\mu \mathrm{g} / \mathrm{kg}$ feed) were shown to result in more pronounced toxic effects $[71,104]$ and decreased plasma albumin, and histopathological changes in the liver and kidney were only observed in broiler chickens orally receiving $2500 \mu \mathrm{g} \mathrm{AFB} 1 / \mathrm{kg}$ and 10,000 $\mu \mathrm{g} \mathrm{FB1} / \mathrm{kg}$ [111]. Chang et al. [64] reported that the combined effects of AFB1 (50 $\mu \mathrm{g} / \mathrm{kg}$ feed) and ZEN (500 $\mu \mathrm{g} / \mathrm{kg}$ feed) resulted in increased ZEN residues and histopathological changes in broiler chickens' organs. Moreover, AFB1 and OTA, both at levels of $100 \mu \mathrm{g} / \mathrm{kg}$ feed, caused pronounced decreases in BW and OTA residues in the livers of broiler chickens [83]. Liu et al. [58] demonstrated that reduced feed intake and BW gain in broiler chickens were due to the toxic effects of DON (1500 or $5000 \mu \mathrm{g} / \mathrm{kg}$ feed) and FBs $(20,000 \mu \mathrm{g} / \mathrm{kg}$ feed). Long-term feeding of diets contaminated with DON, FBs, and ZEN or DON, ZEN, and diacetoxyscirpenol below the EU regulatory limits resulted in increased FCR in broiler chickens [16]. Moreover, the combined toxic effects of DON (20,000 $\mu \mathrm{g} / \mathrm{kg}$ feed), FBs (5000 $\mu \mathrm{g} / \mathrm{kg}$ feed), and ZEN (500 $\mu \mathrm{g} / \mathrm{kg}$ feed) were manifested through increased residues of ZEN and its metabolites in livers of broiler chickens [112]. Gentles et al. [85] reported the highest (35\%) reduction in BW gain and pronounced changes in blood biochemicals in broiler chickens due to the combined toxicities of CPA $(34,000 \mu \mathrm{g} / \mathrm{kg}$ feed $)$ and OTA $(2500 \mu \mathrm{g} / \mathrm{kg}$ feed). Furthermore, the additive toxic effects of $567 \mu \mathrm{g}$ OTA $/ \mathrm{kg}$ feed and $927 \mu \mathrm{g} \mathrm{T}-2 / \mathrm{kg}$ caused pronounced reduction in BWG and liver and kidney histological changes [66]. Reduced immune function in broiler chickens resulted from the additive immunosuppressive effects of CPA $(10,000 \mu \mathrm{g} / \mathrm{kg}$ feed $)$ and T-2 (1000 $\mu \mathrm{g} / \mathrm{kg}$ feed) [93] or T-2 (500 $\mu \mathrm{g} / \mathrm{kg}$ feed) and OTA (250 $\mu \mathrm{g} / \mathrm{kg}$ feed) [17]. In contrary results, feeding FBs, ZEN, and DON at maximum EU-recommended values 
was reported to cause no toxicological interactions on broiler chickens' productivity and health $[59,113]$.

\section{Postharvest Mycotoxin Mitigation Strategies in Broiler and Layer Chicken Production}

Figure 1 highlights techniques of preventing mycotoxin formation in crops while in the field, during transportation, and in storage. Preventing mycotoxin formation can be impractical especially with changing climatic conditions, and feasible techniques for mycotoxin decontamination, especially in feeds, have been reported to include the use of clay-based mycotoxin binders that function when the mycotoxin is already present in the diets and is being ingested by an animal [55]. They are suitable for situations where regular testing of feeds is not practical or where there is a common practice of using spoiled grains for feed formulations, such as in SSA $[19,114]$.

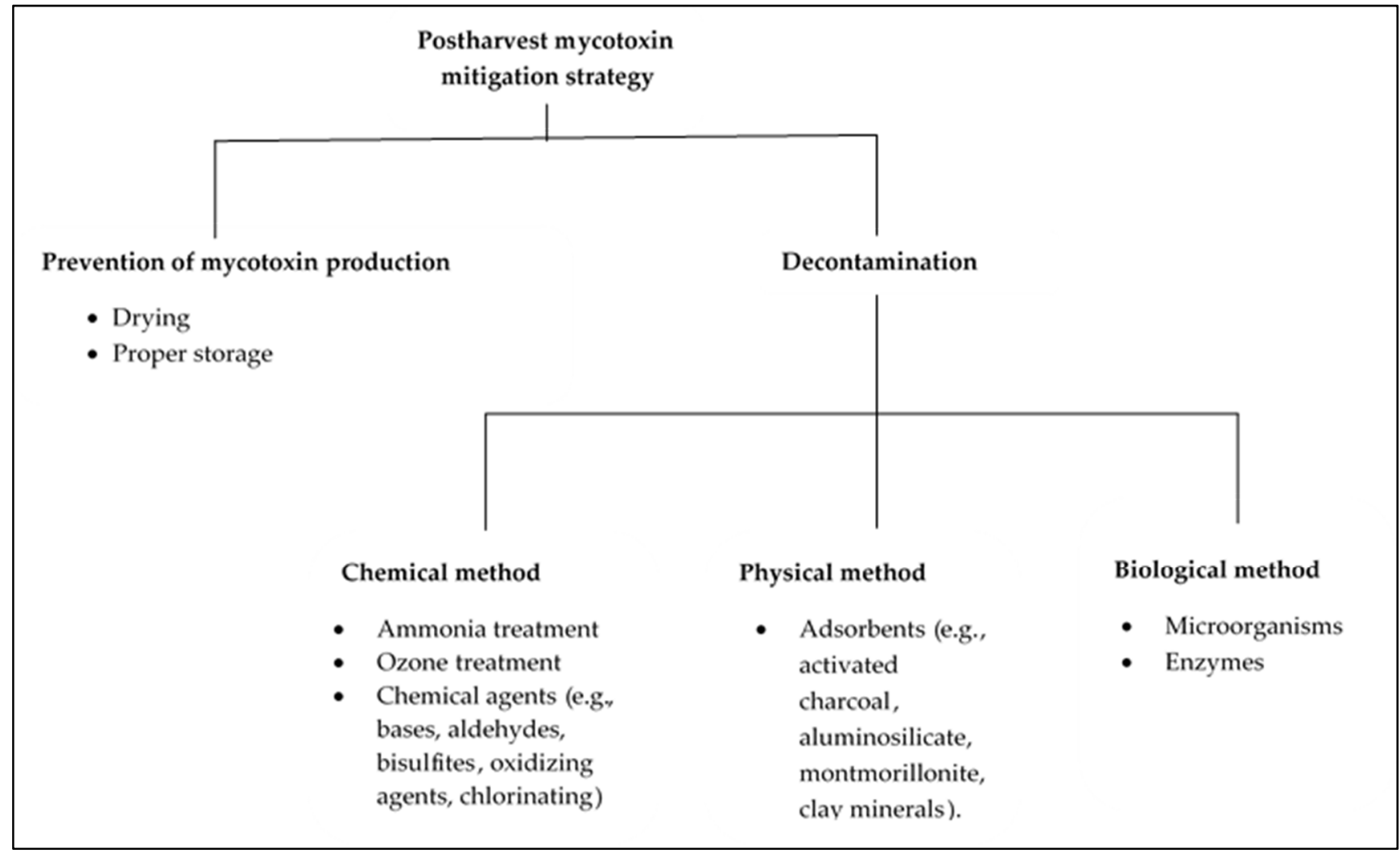

Figure 1. Diagrammatic representation for postharvest mycotoxin mitigation strategies in broiler and layer chickens' production.

Commercial clay-based mycotoxin binders are available in SSA countries, such as Nigeria [51], Kenya [114,115], and Tanzania [116], and are imported by feed processors for use in feed formulations. In most SSA countries, such as Kenya, there is no information on efficacy, safety, and regulations for use of these clay mycotoxin binders [115]. In Nigeria, commercial mycotoxin binders were shown to protect broiler chickens from the toxic effects of AFs [50,51]. In Tanzania, local clay collected from one of the regions had a good affinity for AFB1 in vitro and was relatively comparable to the commercial mycotoxin binder used in the study [116]. The use of locally available mycotoxin binders can be an economical solution for mycotoxin problems in SSA, thereby making poultry production more costeffective; however, more trials and studies in SSA are needed to evaluate the safety and efficacy of the locally available mycotoxin binders, as the trials cited below are from outside the region. 
Hydrated sodium calcium aluminosilicate (HSCAS) has a high affinity to adsorb AFB1 in vitro and prevented the negative effects of AFs in chickens in vivo [98]. Chen et al. [97], however, reported partial protection of HSCAS against the toxic effects of AFs in broiler chickens. Furthermore, HSCAS failed to completely protect broiler chickens from the toxic effects of CPA [117] and T-2 [106], indicating that the efficacy of HSCAS may be affected by the level and nature of the mycotoxin. Other clay-based compounds, including bentonite, montmorillonite, and zeolite, were also shown to ameliorate the toxic effects of AFs on chickens $[72,74,75,103,109,118,119]$. Clay-based compounds were reported to alleviate the toxic effects of DON in broiler chickens, although other studies have reported that these compounds are not effective against trichothecenes [105]. In contrary results, clay-based compounds, including bentonite binder, failed to completely ameliorate the toxic effects of AFs $[66,69]$ or FBs [99]. These latter studies further demonstrate the need for an in-depth characterization of mycotoxin-binding agents for use in a given mycotoxin contamination and suitable in vivo models of target animal species to guarantee their efficacy and safety. Additionally, more research is needed to evaluate the efficiency of mycotoxin binders in the presence of more than one mycotoxin, as is common under field conditions. In experimental trials, bentonite clays were reported to protect chickens from the combined toxic effects of AFs and FBs [73] as well as AFs and OTA [83]. Additionally, another mycotoxin detoxifier consisting of a binding clay and modifying enzymes was shown to partially counteract the combined effects of OTA and T-2 toxin at levels below the CFIA-tolerated maximum limits in poultry feeds [17].

Another way of reducing the negative effects of mycotoxins already ingested and present in the gastrointestinal tract of animals involves the use of mycotoxin modifiers, such as enzymes, fungi, and bacteria, to degrade the mycotoxins into less toxic metabolites. Recently, the inclusion of Lactobacillus spp. in broiler chickens' diets was shown to alleviate the toxic effects of AFB1 or AFB1 and ZEN [64] as well as DON [80]. Ma et al. [120] further demonstrated that Bacillus subtilis ANSB060 from fish gut ameliorated the toxic effects of AFB1 on layer chickens. Moreover, the bovine rumen bacterial strain (Eubacterium $B B S H$ 797) was able to deactivate DON, forming the less toxic deepoxy-deoxynivalenol (DOM-1) [121]. Fumonisin esterase enzymes have also been shown to degrade FBs and form less toxic metabolites, including hydrolyzed fumonisin B1 (HFB1) and partially hydrolyzed fumonisin B1 (pHFB1) [122]. Inclusion of the esterase enzymes in poultry diets was reported to be safe for chickens and turkeys and efficiently degraded FBs at levels even below the EU guidance limits of 20,000 $\mu \mathrm{g} / \mathrm{kg}$ [122]. Yeast strains have also been reported to modulate the biotransformation of OTA to less toxic OTA metabolites in ex vivo and in vivo chicken models [123]. Furthermore, Trichosporon mycotoxinivorans, a yeast strain from the hindgut of the termite Mastotermes darwiniensis, was shown to degrade OTA and ZEN to less toxic metabolites [121,124] or reduce OTA depositions in tissues [67]. Yeast cell wall extracts were also shown to have promising results in preventing the negative effects of OTA [68] and offered partial protection against the toxic effects of AFs, FBs, DON, and ZEN [95]. Microorganisms are thus suitable for the biodegradation of some mycotoxins, especially trichothecenes, which are poorly adsorbed by mycotoxin binders. However, their efficacy both practically and economically needs to be widely evaluated before commercial applications.

\section{Conclusions}

Poultry feed and feed ingredients from SSA are contaminated with mycotoxins, and co-occurrences of mycotoxins, especially AFs and FBs, are frequently observed due to colonization of feed ingredients by different mycotoxin-producing fungi. The mycotoxins have a negative impact on the health and productivity of layer and broiler chickens, resulting in significant economic losses. Additionally, chronic exposure to low levels of mycotoxins in poultry products, including eggs, meat, and liver, poses a safety concern to human consumers of these products. Few SSA countries have regulatory limits or guidance values for various mycotoxins in poultry feeds. More occurrence and toxicological information 
are therefore required to help monitor and control mycotoxin contamination in SSA. In addition, the safety and efficacy of local clay compounds from SSA as binding agents should be evaluated to provide suitable locally available solutions to mycotoxin problems.

Author Contributions: Conceptualization, G.A., M.-L.S. and J.F.L.; writing-original draft preparation, P.E.O.; writing—review and editing, P.E.O., M.-L.S., D.C.K., S.C., S.O., E.K.K., B.D., J.K.G., J.F.L. and G.A.; supervision, G.A., M.-L.S., J.F.L., S.O., S.C., J.K.G., J.F.L. and E.K.K.; project coordination, G.A. and S.C.; funding acquisition, G.A., S.C., M.-L.S. and J.K.G. All authors have read and agreed to the published version of the manuscript.

Funding: This research was conducted within the ERA-NET LEAP-Agri MycoSafe-South project funded by the Belgian Federal Science Policy Office (BELSPO) (contract number BL/02/LeapAgri 01), Belgian National Fund for Scientific Research (NFSR), Research Council of Norway (RCN) (grant number 290459), Kenyan Ministry of Education, Science and Technology (MoEST), South Africa's National Research Foundation (NRF) and BIOMIN Holding GmbH and Harbro Ltd. The time of JFL was supported by the CGIAR research program on Agriculture for Nutrition and Health. GA was supported by the Ghent University Chair Poultry Health Sciences.

Conflicts of Interest: The authors declare no conflict of interest.

\section{References}

1. Mthiyane, D.M.N.; Mhlanga, B.S. The nutritive value of marula (Sclerocarya birrea) seed cake for broiler chickens: Nutritional composition, performance, carcass characteristics and oxidative and mycotoxin status. Trop. Anim. Health Prod. 2017, 49, 835-842. [CrossRef] [PubMed]

2. Dana, N. Poultry Sector Ethiopia. In FAO Animal Production and Health Livestock Country Reviews; FAO: Rome, Italy, $2019 ;$ p. 60.

3. Christensen, P.; Gillingham, K.; Nordhaus, W. Uncertainty in forecasts of long-run economic growth. Proc. Natl. Acad. Sci. USA 2018, 115, 5409-5414. [CrossRef]

4. Aboagye-Nuamah, F.; Kwoseh, C.K.; Maier, D.E. Toxigenic mycoflora, aflatoxin and fumonisin contamination of poultry feeds in Ghana. Toxicon 2021, 198, 164-170. [CrossRef]

5. Vernooij, A.; Masaki, M.N.; Meijer-Willems, D. Regionalisation in Poultry Development in Eastern Africa; Wageningen Livestock Research: Wageningen, The Netherlands, 2018. [CrossRef]

6. Njobeh, P.B.; Dutton, M.F.; Åberg, A.T.; Haggblom, P. Estimation of Multi-Mycotoxin Contamination in South African Compound Feeds. Toxins 2012, 4, 836-848. [CrossRef] [PubMed]

7. Ssepuuya, G.; Namulawa, V.; Mbabazi, D.; Mugerwa, S.; Fuuna, P.; Nampijja, Z.; Ekesi, S.; Fiaboe, K.; Nakimbugwe, D. Use of insects for fish and poultry compound feed in sub-Saharan Africa-A systematic review. J. Insects Food Feed 2017, 3, $289-302$. [CrossRef]

8. Akinmusire, O.O.; El-Yuguda, A.-D.; Musa, J.A.; Oyedele, O.A.; Sulyok, M.; Somorin, Y.; Ezekiel, C.N.; Krska, R. Mycotoxins in poultry feed and feed ingredients in Nigeria. Mycotoxin Res. 2018, 35, 149-155. [CrossRef] [PubMed]

9. Peng, W.-X.; Marchal, J.; van der Poel, A. Strategies to prevent and reduce mycotoxins for compound feed manufacturing. Anim. Feed Sci. Technol. 2018, 237, 129-153. [CrossRef]

10. Kemboi, D.C.; Ochieng, P.E.; Antonissen, G.; Croubels, S.; Scippo, M.-L.; Okoth, S.; Kang'the, E.K.; Faas, J.; Doupovec, B.; Lindahl, J.F.; et al. Multi-Mycotoxin Occurrence in Dairy Cattle and Poultry Feeds and Feed Ingredients from Machakos Town, Kenya. Toxins 2020, 12, 762. [CrossRef]

11. Nakavuma, J.L.; Kirabo, A.; Bogere, P.; Nabulime, M.M.; Kaaya, A.N.; Gnonlonfin, B. Awareness of mycotoxins and occurrence of aflatoxins in poultry feeds and feed ingredients in selected regions of Uganda. Int. J. Food Contam. 2020, 7, 1-10. [CrossRef]

12. Okoth, S.; De Boevre, M.; Vidal, A.; Di Mavungu, J.D.; Landschoot, S.; Kyallo, M.; Njuguna, J.; Harvey, J.; De Saeger, S. Genetic and Toxigenic Variability within Aspergillus flavus Population Isolated from Maize in Two Diverse Environments in Kenya. Front. Microbiol. 2018, 9, 57. [CrossRef]

13. Kana, J.R.; Gnonlonfin, B.G.J.; Harvey, J.; Wainaina, J.; Wanjuki, I.; Skilton, R.A.; Teguia, A. Assessment of Aflatoxin Contamination of Maize, Peanut Meal and Poultry Feed Mixtures from Different Agroecological Zones in Cameroon. Toxins 2013, 5, 884-894. [CrossRef]

14. Sirma, A.; Lindahl, J.; Makita, K.; Senerwa, D.; Mtimet, N.; Kang'ethe, E.; Grace, D. The impacts of aflatoxin standards on health and nutrition in sub-Saharan Africa: The case of Kenya. Glob. Food Secur. 2018, 18, 57-61. [CrossRef]

15. Nishimwe, K.; Bowers, E.; Ayabagabo, J.D.D.; Habimana, R.; Mutiga, S.; Maier, D. Assessment of Aflatoxin and Fumonisin Contamination and Associated Risk Factors in Feed and Feed Ingredients in Rwanda. Toxins 2019, 11, 270. [CrossRef]

16. Kolawole, O.; Graham, A.; Donaldson, C.; Owens, B.; Abia, W.A.; Meneely, J.; Alcorn, M.J.; Connolly, L.; Elliott, C.T. Low Doses of Mycotoxin Mixtures below EU Regulatory Limits Can Negatively Affect the Performance of Broiler Chickens: A Longitudinal Study. Toxins 2020, 12, 433. [CrossRef]

17. Xue, C.Y.; Wang, G.H.; Chen, F.; Zhang, X.B.; Bi, Y.Z.; Cao, Y.C. Immunopathological effects of ochratoxin A and T-2 toxin combination on broilers. Poult. Sci. 2010, 89, 1162-1166. [CrossRef] [PubMed] 
18. Placinta, C.; D'Mello, J.; Macdonald, A. A review of worldwide contamination of cereal grains and animal feed with Fusarium mycotoxins. Anim. Feed Sci. Technol. 1999, 78, 21-37. [CrossRef]

19. Kemboi, D.C.; Antonissen, G.; Ochieng, P.E.; Croubels, S.; Okoth, S.; Kang'the, E.K.; Faas, J.; Lindahl, J.F.; Gathumbi, J.K. A Review of the Impact of Mycotoxins on Dairy Cattle Health: Challenges for Food Safety and Dairy Production in Sub-Saharan Africa. Toxins 2020, 12, 222. [CrossRef] [PubMed]

20. Siame, B.A.; Mpuchane, S.F.; Gashe, B.A.; Allotey, J.; Teffera, G. Occurrence of Aflatoxins, Fumonisin B1, and Zearalenone in Foods and Feeds in Botswana. J. Food Prot. 1998, 61, 1670-1673. [CrossRef] [PubMed]

21. Ayalew, A. Mycotoxins and surface and internal fungi of maize from Ethiopia. Afr. J. Food Agric. Nutr. Dev. 2010, 10, 4109-4123. [CrossRef]

22. Chala, A.; Mohammed, A.; Ayalew, A.; Skinnes, H. Natural occurrence of aflatoxins in groundnut (Arachis hypogaea L.) from eastern Ethiopia. Food Control 2013, 30, 602-605. [CrossRef]

23. Worku, A.F.; Abera, M.; Kalsa, K.K.; Subramanyam, B.; Habtu, N.G. Occurrence of Mycotoxins in Stored Maize in Ethiopia. Ethiop. J. Agric. Sci. 2019, 13, 31-43.

24. Mwalwayo, D.S.; Thole, B. Prevalence of aflatoxin and fumonisins $\left(\mathrm{B}_{1}+\mathrm{B}_{2}\right)$ in maize consumed in rural Malawi. Toxicol. Rep. 2016, 3, 173-179. [CrossRef] [PubMed]

25. Gruber-Dorninger, C.; Jenkins, T.; Schatzmayr, G. Multi-mycotoxin screening of feed and feed raw materials from Africa. World Mycotoxin J. 2018, 11, 369-383. [CrossRef]

26. Mmongoyo, J.A.; Wu, F.; Linz, J.E.; Nair, M.G.; Mugula, J.K.; Tempelman, R.; Strasburg, G.M. Aflatoxin levels in sunflower seeds and cakes collected from micro- and small-scale sunflower oil processors in Tanzania. PLoS ONE 2017, 12, e0175801. [CrossRef] [PubMed]

27. Nyangi, C.; Mugula, J.K.; Beed, F.; Boni, S.K.E.; Sulyok, M.M. Aflatoxins and fumonisin contamination of marketed maize, maize bran and maize used as animal feed in Northern Tanzania. Afr. J. Food Agric. Nutr. Dev. 2016, 16, 11054-11065. [CrossRef]

28. Ediage, E.N.; Di Mavungu, J.D.; Monbaliu, S.; Van Peteghem, C.; De Saeger, S. A Validated Multianalyte LC-MS/MS Method for Quantification of 25 Mycotoxins in Cassava Flour, Peanut Cake and Maize Samples. J. Agric. Food Chem. 2011, 59, 5173-5180. [CrossRef]

29. Getachew, A.; Chala, A.; Hofgaard, I.S.; Brurberg, M.B.; Sulyok, M.; Tronsmo, A.-M. Multimycotoxin and fungal analysis of maize grains from south and southwestern Ethiopia. Food Addit. Contam. Part B 2017, 11, 64-74. [CrossRef]

30. Yilma, S.; Sadessa, K.; Kebede, D. Fungal Infections and Aflatoxin Contamination in Maize Grains Collected from West Showa and East Wallega Zones, Ethiopia. Int. J. Curr. Res. Rev. 2019, 11, 16-22. [CrossRef]

31. Ezekiel, C.; Bandyopadhyay, R.; Sulyok, M.; Warth, B.; Krska, R. Fungal and bacterial metabolites in commercial poultry feed from Nigeria. Food Addit. Contam. Part A 2012, 29, 1288-1299. [CrossRef]

32. Ezekiel, C.; Sulyok, M.; Warth, B.; Odebode, A.; Krska, R. Natural occurrence of mycotoxins in peanut cake from Nigeria. Food Control 2012, 27, 338-342. [CrossRef]

33. Mokubedi, S.M.; Phoku, J.Z.; Changwa, R.N.; Gbashi, S.; Njobeh, P.B. Analysis of Mycotoxins Contamination in Poultry Feeds Manufactured in Selected Provinces of South Africa Using UHPLC-MS/MS. Toxins 2019, 11, 452. [CrossRef]

34. Rodrigues, I.; Handl, J.; Binder, E. Mycotoxin occurrence in commodities, feeds and feed ingredients sourced in the Middle East and Africa. Food Addit. Contam. Part B 2011, 4, 168-179. [CrossRef]

35. Mohammed, A.; Chala, A.; Dejene, M.; Fininsa, C.; Hoisington, D.A.; Sobolev, V.S.; Arias, R.S. Aspergillus and aflatoxin in groundnut (Arachis hypogaea L.) and groundnut cake in Eastern Ethiopia. Food Addit. Contam. Part B 2016, 9, 290-298. [CrossRef]

36. Antonissen, G.; Martel, A.; Pasmans, F.; Ducatelle, R.; Verbrugghe, E.; Vandenbroucke, V.; Li, S.; Haesebrouck, F.; Van Immerseel, F.; Croubels, S. The Impact of Fusarium Mycotoxins on Human and Animal Host Susceptibility to Infectious Diseases. Toxins 2014, 6, 430-452. [CrossRef]

37. Mngadi, P.T.; Govinden, R.; Odhav, B. Co-Occurring Mycotoxins in Animal Feeds. Afr. J. Biotechnol. $2008,7,5$.

38. Olopade, B.K.; Oranusi, S.U.; Nwinyi, O.C.; Gbashi, S.; Njobeh, P.B. Occurrences of Deoxynivalenol, Zearalenone and some of their masked forms in selected cereals from Southwest Nigeria. NFS J. 2021, 23, 24-29. [CrossRef]

39. Pouokam, G.B.; Foudjo, B.U.S.; Samuel, C.; Yamgai, P.F.; Silapeux, A.K.; Sando, J.T.; Atonde, G.F.; Frazzoli, C. Contaminants in Foods of Animal Origin in Cameroon: A One Health Vision for Risk Management "from Farm to Fork". Front. Public Health 2017, 5, 197. [CrossRef] [PubMed]

40. Meerpoel, C.; Vidal, A.; Tangni, E.K.; Huybrechts, B.; Couck, L.; De Rycke, R.; De Bels, L.; De Saeger, S.; Broeck, W.V.D.; Devreese, M.; et al. A Study of Carry-Over and Histopathological Effects after Chronic Dietary Intake of Citrinin in Pigs, Broiler Chickens and Laying Hens. Toxins 2020, 12, 719. [CrossRef] [PubMed]

41. Emmanuel, K.E.; Els, V.P.; Bart, H.; Evelyne, D.; Els, D. Carry-over of some Fusarium mycotoxins in tissues and eggs of chickens fed experimentally mycotoxin-contaminated diets. Food Chem. Toxicol. 2020, 145, 111715. [CrossRef]

42. Sineque, A.; Macuamule, C.L.; Dos Anjos, F.R. Aflatoxin B1 Contamination in Chicken Livers and Gizzards from Industrial and Small Abattoirs, Measured by ELISA Technique in Maputo, Mozambique. Int. J. Environ. Res. Public Health 2017, 14, 951. [CrossRef]

43. Tardieu, D.; Travel, A.; Le Bourhis, C.; Metayer, J.-P.; Mika, A.; Cleva, D.; Boissieu, C.; Guerre, P. Fumonisins and zearalenone fed at low levels can persist several days in the liver of turkeys and broiler chickens after exposure to the contaminated diet was stopped. Food Chem. Toxicol. 2021, 148, 111968. [CrossRef] 
44. Iqbal, S.Z.; Nisar, S.; Asi, M.R.; Jinap, S. Natural incidence of aflatoxins, ochratoxin A and zearalenone in chicken meat and eggs. Food Control 2014, 43, 98-103. [CrossRef]

45. Sypecka, Z.; Kelly, M.; Brereton, P. Deoxynivalenol and Zearalenone Residues in Eggs of Laying Hens Fed with a Naturally Contaminated Diet: Effects on Egg Production and Estimation of Transmission Rates from Feed to Eggs. J. Agric. Food Chem. 2004, 52, 5463-5471. [CrossRef]

46. Tchana, A.N.; Moundipa, P.F.; Tchouanguep, F.M. Aflatoxin Contamination in Food and Body Fluids in Relation to Malnutrition and Cancer Status in Cameroon. Int. J. Environ. Res. Public Health 2010, 7, 178-188. [CrossRef]

47. Okoth, S. Improving the Evidence Base on Aflatoxin Contamination and Exposure in Africa: Strengthening the Agriculture-Nutrition Nexus; Partnership for Aflatoxin Control in Africa: Addis Ababa, Ethiopia, 2016; p. 128.

48. Ngindu, A.; Kenya, P.; Ocheng, D.; Omondi, T.; Ngare, W.; Gatei, D.; Johnson, B.; Ngira, J.; Nandwa, H.; Jansen, A.; et al. Outbreak of acute hepatitis caused by aflatoxin poisoning in kenya. Lancet 1982, 319, 1346-1348. [CrossRef]

49. Kang'ethe, E. Situation Analysis: Improving Food Safety in the Maize Value Chain in Kenya; Report Prepared for the Food and Agriculture Organization of the United Nations; University of Nairobi: Nairobi, Kenya, 2011.

50. Mgbeahuruike, A.; Ejiofor, T.; Ashang, M.; Ojiako, C.; Obasi, C.; Ezema, C.; Okoroafor, O.; Mwanza, M.; Karlsson, M.; Chah, K. Reduction of the Adverse Impacts of Fungal Mycotoxin on Proximate Composition of Feed and Growth Performance in Broilers by Combined Adsorbents. Toxins 2021, 13, 430. [CrossRef] [PubMed]

51. Aikore, M.O.S.; Ortega-Beltran, A.; Eruvbetine, D.; Atehnkeng, J.; Falade, T.D.O.; Cotty, P.J.; Bandyopadhyay, R. Performance of Broilers Fed with Maize Colonized by Either Toxigenic or Atoxigenic Strains of Aspergillus flavus with and without an Aflatoxin-Sequestering Agent. Toxins 2019, 11, 565. [CrossRef] [PubMed]

52. Fernandez, A.; Verde, M.T.; Gascon, M.; Ramos, J.; Gomez, J.; Luco, D.F.; Chavez, G. Variations of clinical biochemical parameters of laying hens and broiler chickens fed aflatoxin-containing feed. Avian Pathol. 1994, 23, 37-47. [CrossRef]

53. Hernández-Ramírez, J.O.; Nava-Ramírez, M.J.; Merino-Guzmán, R.; Téllez-Isaías, G.; Vázquez-Durán, A.; Méndez-Albores, A. The effect of moderate-dose aflatoxin B1 and Salmonella Enteritidis infection on intestinal permeability in broiler chickens. Mycotoxin Res. 2020, 36, 31-39. [CrossRef] [PubMed]

54. Saleemi, M.K.; Ashraf, K.; Gul, S.T.; Naseem, M.N.; Sajid, M.S.; Mohsin, M.; He, C.; Zubair, M.; Khan, A. Toxicopathological effects of feeding aflatoxins B1 in broilers and its ameliosration with indigenous mycotoxin binder. Ecotoxicol. Environ. Saf. 2020, 187, 109712. [CrossRef]

55. Monson, M.S.; Coulombe, R.A.; Reed, K.M. Aflatoxicosis: Lessons from Toxicity and Responses to Aflatoxin B1 in Poultry. Agriculture 2015, 5, 742-777. [CrossRef]

56. Weibking, T.S.; LeDoux, D.R.; Bermudez, A.J.; Turk, J.R.; Rottinghaus, G.E.; Wang, E.; Merrill, A.H. Effects of Feeding Fusarium moniliforme Culture Material, Containing Known Levels of Fumonisin B1, on the Young Broiler Chick. Poult. Sci. 1993, 72, 456-466. [CrossRef]

57. Antonissen, G.; De Baere, S.; Novak, B.; Schatzmayr, D.; den Hollander, D.; Devreese, M.; Croubels, S. Toxicokinetics of Hydrolyzed Fumonisin B1 after Single Oral or Intravenous Bolus to Broiler Chickens Fed a Control or a Fumonisins-Contaminated Diet. Toxins 2020, 12, 413. [CrossRef]

58. Liu, J.; Doupovec, B.; Schatzmayr, D.; Murugesan, G.; Bortoluzzi, C.; Villegas, A.; Applegate, T. The impact of deoxynivalenol, fumonisins, and their combination on performance, nutrient, and energy digestibility in broiler chickens. Poult. Sci. 2020, 99, 272-279. [CrossRef] [PubMed]

59. Metayer, J.-P.; Travel, A.; Mika, A.; Bailly, J.-D.; Cleva, D.; Boissieu, C.; Le Guennec, J.; Froment, P.; Albaric, O.; Labrut, S.; et al. Lack of Toxic Interaction Between Fusariotoxins in Broiler Chickens Fed throughout Their Life at the Highest Level Tolerated in the European Union. Toxins 2019, 11, 455. [CrossRef]

60. Antonissen, G.; Croubels, S.; Pasmans, F.; Ducatelle, R.; Eeckhaut, V.; Devreese, M.; Verlinden, M.; Haesebrouck, F.; Eeckhout, M.; De Saeger, S.; et al. Fumonisins affect the intestinal microbial homeostasis in broiler chickens, predisposing to necrotic enteritis. Vet. Res. 2015, 46, 1-11. [CrossRef] [PubMed]

61. Grenier, B.; Dohnal, I.; Shanmugasundaram, R.; Eicher, S.D.; Selvaraj, R.K.; Schatzmayr, G.; Applegate, T.J. Susceptibility of Broiler Chickens to Coccidiosis When Fed Subclinical Doses of Deoxynivalenol and Fumonisins-Special Emphasis on the Immunological Response and the Mycotoxin Interaction. Toxins 2016, 8, 231. [CrossRef]

62. Chen, S.S.; Li, Y.-H.; Lin, M.-F. Chronic Exposure to the Fusarium Mycotoxin Deoxynivalenol: Impact on Performance, Immune Organ, and Intestinal Integrity of Slow-Growing Chickens. Toxins 2017, 9, 334. [CrossRef]

63. Yu, Y.-H.; Hsiao, F.S.-H.; Proskura, W.S.; Dybus, A.; Siao, Y.-H.; Cheng, Y.-H. An impact of Deoxynivalenol produced by Fusarium graminearum on broiler chickens. J. Anim. Physiol. Anim. Nutr. 2018, 102, 1012-1019. [CrossRef]

64. Chang, J.; Wang, T.; Wang, P.; Yin, Q.; Liu, C.; Zhu, Q.; Lu, F.; Gao, T. Compound probiotics alleviating aflatoxin B1 and zearalenone toxic effects on broiler production performance and gut microbiota. Ecotoxicol. Environ. Saf. 2020, 194, 110420. [CrossRef] [PubMed]

65. Chen, Y.; Cheng, Y.; Wen, C.; Wang, W.; Kang, Y.; Wang, A.; Zhou, Y. The protective effects of modified palygorskite on the broilers fed a purified zearalenone-contaminated diet. Poult. Sci. 2019, 98, 3802-3810. [CrossRef]

66. García, A.R.; Avila, E.; Rosiles, R.; Petrone, V.M. Evaluation of Two Mycotoxin Binders to Reduce Toxicity of Broiler Diets Containing Ochratoxin A and T-2 Toxin Contaminated Grain. Avian Dis. 2003, 47, 691-699. [CrossRef] 
67. Bhatti, S.A.; Khan, M.Z.; Saleemi, M.K.; Hassan, Z.U. Impact of dietary Trichosporon mycotoxinivorans on ochratoxin A induced immunotoxicity; In vivo study. Food Chem. Toxicol. 2019, 132, 110696. [CrossRef]

68. Vartiainen, S.; Yiannikouris, A.; Apajalahti, J.; Moran, A.C. Comprehensive Evaluation of the Efficiency of Yeast Cell Wall Extract to Adsorb Ochratoxin A and Mitigate Accumulation of the Toxin in Broiler Chickens. Toxins 2020, 12, 37. [CrossRef] [PubMed]

69. Shannon, T.A.; Ledoux, D.R.; Rottinghaus, G.E.; Shaw, D.P.; Daković, A.; Marković, M. The efficacy of raw and concentrated bentonite clay in reducing the toxic effects of aflatoxin in broiler chicks. Poult. Sci. 2017, 96, 1651-1658. [CrossRef] [PubMed]

70. Bintvihok, A.; Kositcharoenkul, S. Effect of dietary calcium propionate on performance, hepatic enzyme activities and aflatoxin residues in broilers fed a diet containing low levels of aflatoxin B1. Toxicon 2006, 47, 41-46. [CrossRef]

71. Tessari, E.; Oliveira, C.; Cardoso, A.; Le Doux, D.; Rottinghaus, G. Effects of aflatoxin B1and fumonisin B1on body weight, antibody titres and histology of broiler chicks. Br. Poult. Sci. 2006, 47, 357-364. [CrossRef] [PubMed]

72. Dos Anjos, F.R.; Le Doux, D.R.; Rottinghaus, G.E.; Chimonyo, M. Efficacy of adsorbents (bentonite and diatomaceous earth) and turmeric (Curcuma longa) in alleviating the toxic effects of aflatoxin in chicks. Br. Poult. Sci. 2015, 56, 459-469. [CrossRef]

73. Miazzo, R.; Peralta, M.F.; Magnoli, C.; Salvano, M.; Ferrero, S.; Chiacchiera, S.; Carvalho, E.C.Q.; Rosa, C.A.R.; Dalcero, A. Efficacy of sodium bentonite as a detoxifier of broiler feed contaminated with aflatoxin and fumonisin. Poult. Sci. 2005, 84, 1-8. [CrossRef]

74. Santurio, J. Effect of sodium bentonite on the performance and blood variables of broiler chickens intoxicated with aflatoxins. Br. Poult. Sci. 1999, 40, 115-119. [CrossRef]

75. Rosa, C.A.R.; Miazzo, R.; Magnoli, C.; Salvano, M.; Chiacchiera, S.M.; Ferrero, S.; Saenz, M.; Carvalho, E.C.Q.; Dalcero, A. Evaluation of the Efficacy of Bentonite from the South of Argentina to Ameliorate the Toxic Effects of Aflatoxin in Broilers. Poult. Sci. 2001, 80, 139-144. [CrossRef]

76. Pimpukdee, K.; Kubena, L.F.; Bailey, C.A.; Huebner, H.J.; Afriyie-Gyawu, E.; Phillips, T.D. Aflatoxin-induced toxicity and depletion of hepatic vitamin A in young broiler chicks: Protection of chicks in the presence of low levels of NovaSil PLUS in the diet. Poult. Sci. 2004, 83, 737-744. [CrossRef] [PubMed]

77. Salwa, A.A.; Anwer, W. Effect of Naturally Contaminated Feed with Aflatoxins on Performance of Laying Hens and the Carryover of Aflatoxin B1 Residues in Table Eggs. Pak. J. Nutr. 2009, 8, 181-186. [CrossRef]

78. Zaghini, A.; Martelli, G.; Roncada, P.; Simioli, M.; Rizzi, L. Mannanoligosaccharides and aflatoxin B1 in feed for laying hens: Effects on egg quality, aflatoxins B1 and M1 residues in eggs, and aflatoxin B1 levels in liver. Poult. Sci. 2005, 84, 825-832. [CrossRef] [PubMed]

79. Riahi, I.; Marquis, V.; Ramos, A.J.; Brufau, J.; Esteve-Garcia, E.; Pérez-Vendrell, A.M. Effects of Deoxynivalenol-Contaminated Diets on Productive, Morphological, and Physiological Indicators in Broiler Chickens. Animals 2020, 10, 1795. [CrossRef] [PubMed]

80. De Souza, M.; Baptista, A.A.S.; Valdiviezo, M.J.; Justino, L.; Menck-Costa, M.F.; Ferraz, C.R.; da Gloria, E.M.; Verri, W.A.; Bracarense, A.P.F. Lactobacillus spp. reduces morphological changes and oxidative stress induced by deoxynivalenol on the intestine and liver of broilers. Toxicon 2020, 185, 203-212. [CrossRef] [PubMed]

81. Rauber, R.H.; Dilkin, P.; Mallmann, A.O.; Marchioro, A.; Mallmann, C.; Borsoi, A.; Nascimento, V.P.D. Individual and combined effects of Salmonella typhimurium lipopolysaccharide and fumonisin B1 in broiler chickens. Poult. Sci. 2012, 91, $2785-2791$. [CrossRef]

82. Solcan, C.; Pavel, G.; Floristean, V.C.; Chiriac, I.S.B.; Şlencu, B.G.; Solcan, G. Effect of ochratoxin A on the intestinal mucosa and mucosa-associated lymphoid tissues in broiler chickens. Acta Vet. Hung. 2015, 63, 30-48. [CrossRef]

83. Pappas, A.C.; Tsiplakou, E.; Tsitsigiannis, D.I.; Georgiadou, M.; Iliadi, M.K.; Sotirakoglou, K.; Zervas, G. The role of bentonite binders in single or concomitant mycotoxin contamination of chicken diets. Br. Poult. Sci. 2016, 57, 551-558. [CrossRef]

84. Elaroussi, M.; Mohamed, F.; El Barkouky, E.; Atta, A.; Abdou, A.; Hatab, M. Experimental ochratoxicosis in broiler chickens. Avian Pathol. 2006, 35, 263-269. [CrossRef]

85. Gentles, A.; Smith, E.; Kubena, L.; Duffus, E.; Johnson, P.; Thompson, J.; Harvey, R.; Edrington, T. Toxicological evaluations of cyclopiazonic acid and ochratoxin A in broilers. Poult. Sci. 1999, 78, 1380-1384. [CrossRef]

86. Stoev, S.D. Studies on some feed additives and materials giving partial protection against the suppressive effect of ochratoxin A on egg production of laying hens. Res. Vet. Sci. 2010, 88, 486-491. [CrossRef] [PubMed]

87. Chen, Y.; Han, S.; Wang, Y.; Li, D.; Zhao, X.; Zhu, Q.; Yin, H. Oxidative Stress and Apoptotic Changes in Broiler Chicken Splenocytes Exposed to T-2 Toxin. BioMed Res. Int. 2019, 2019, 1-9. [CrossRef] [PubMed]

88. Murugesan, G.R.; Ledoux, D.R.; Naehrer, K.; Berthiller, F.; Applegate, T.; Grenier, B.; Phillips, T.D.; Schatzmayr, G. Prevalence and effects of mycotoxins on poultry health and performance, and recent development in mycotoxin counteracting strategies. Poult. Sci. 2015, 94, 1298-1315. [CrossRef] [PubMed]

89. Naseem, M.N.; Saleemi, M.K.; Khan, A.; Khatoon, A.; Gul, S.T.; Rizvi, F.; Ahmad, I.; Fayyaz, A. Pathological effects of concurrent administration of aflatoxin B1 and fowl adenovirus-4 in broiler chicks. Microb. Pathog. 2018, 121, 147-154. [CrossRef]

90. Cravens, R.L.; Goss, G.R.; Chi, F.; De Boer, E.D.; Davis, S.W.; Hendrix, S.M.; Richardson, J.A.; Johnston, S.L. The effects of necrotic enteritis, aflatoxin B1, and virginiamycin on growth performance, necrotic enteritis lesion scores, and mortality in young broilers. Poult. Sci. 2013, 92, 1997-2004. [CrossRef]

91. Manafi, M.; Mohan, K.; Ali, M.N. Effect of ochratoxin A on coccidiosis-challenged broiler chicks. World Mycotoxin J. 2011, 4, 177-181. [CrossRef] 
92. Girgis, G.N.; Barta, J.; Brash, M.; Smith, T.K. Morphologic Changes in the Intestine of Broiler Breeder Pullets Fed Diets Naturally Contaminated with Fusarium Mycotoxins with or without Coccidial Challenge. Avian Dis. 2010, 54, 67-73. [CrossRef]

93. Kamalavenkatesh, P.; Vairamuthu, S.; Balachandran, C.; Manohar, B.M.; Raj, G.D. Immunopathological effect of the mycotoxins cyclopiazonic acid and T-2 toxin on broiler chicken. Mycopathologia 2005, 159, 273-279. [CrossRef]

94. Yunus, A.W.; Ghareeb, K.; Twarużek, M.; Grajewski, J.; Böhm, J. Deoxynivalenol as a contaminant of broiler feed: Effects on bird performance and response to common vaccines. Poult. Sci. 2012, 91, 844-851. [CrossRef]

95. Li, Z.; Yang, Z.B.; Yang, W.R.; Wang, S.J.; Jiang, S.Z.; Wu, Y.B. Effects of feed-borne Fusarium mycotoxins with or without yeast cell wall adsorbent on organ weight, serum biochemistry, and immunological parameters of broiler chickens. Poult. Sci. 2012, 91, 2487-2495. [CrossRef] [PubMed]

96. Magnoli, A.; Rodriguez, M.; Pereyra, M.G.; Poloni, V.; Peralta, M.; Nilson, A.; Miazzo, R.; Bagnis, G.; Chiacchiera, S.; Cavaglieri, L. Use of yeast (Pichia kudriavzevii) as a novel feed additive to ameliorate the effects of aflatoxin B1 on broiler chicken performance. Mycotoxin Res. 2017, 33, 273-283. [CrossRef]

97. Chen, X.; Horn, N.; Applegate, T.J. Efficiency of hydrated sodium calcium aluminosilicate to ameliorate the adverse effects of graded levels of aflatoxin B1 in broiler chicks. Poult. Sci. 2014, 93, 2037-2047. [CrossRef]

98. Ledoux, D.R.; Rottinghaus, G.; Bermudez, A.; Alonso-Debolt, M. Efficacy of a hydrated sodium calcium aluminosilicate to ameliorate the toxic effects of aflatoxin in broiler chicks. Poult. Sci. 1999, 78, 204-210. [CrossRef] [PubMed]

99. Lee, S.; Kim, D.-H.; Keum, M.-C.; Han, E.; An, B.-K.; Chang, H.-H.; Choi, Y.-H.; Moon, B.-H.; Lee, K.-W. Effects of fumonisin B1 and mycotoxin binders on growth performance, tibia characteristics, gut physiology, and stress indicators in broiler chickens raised in different stocking densities. Poult. Sci. 2018, 97, 845-854. [CrossRef]

100. Lucke, A.; Doupovec, B.; Paulsen, P.; Zebeli, Q.; Böhm, J. Effects of low to moderate levels of deoxynivalenol on feed and water intake, weight gain, and slaughtering traits of broiler chickens. Mycotoxin Res. 2017, 33, 261-271. [CrossRef]

101. El Cafsi, I.; Bjeoui, S.; Rabeh, I.; Nechi, S.; Chelbi, E.; Ghram, A. Effects of ochratoxin A on membrane phospholipids of the intestine of broiler chickens, practical consequences. Animal 2020, 14, 933-941. [CrossRef] [PubMed]

102. Rezar, V.; Frankič, T.; Narat, M.; Levart, A.; Salobir, J. Dose-Dependent Effects of T-2 Toxin on Performance, Lipid Peroxidation, and Genotoxicity in Broiler Chickens. Poult. Sci. 2007, 86, 1155-1160. [CrossRef]

103. Saminathan, M.; Selamat, J.; Pirouz, A.A.; Abdullah, N.; Zulkifli, I. Effects of Nano-Composite Adsorbents on the Growth Performance, Serum Biochemistry, and Organ Weights of Broilers Fed with Aflatoxin-Contaminated Feed. Toxins 2018, 10, 345. [CrossRef]

104. Tessari, E.N.C.; Kobashigawa, E.; Cardoso, A.L.S.P.; LeDoux, D.R.; Rottinghaus, G.E.; Oliveira, C.A.F. Effects of Aflatoxin B1 and Fumonisin B1 on Blood Biochemical Parameters in Broilers. Toxins 2010, 2, 453-460. [CrossRef] [PubMed]

105. Ghareeb, K.; Awad, W.; Böhm, J. Ameliorative effect of a microbial feed additive on infectious bronchitis virus antibody titer and stress index in broiler chicks fed deoxynivalenol. Poult. Sci. 2012, 91, 800-807. [CrossRef]

106. Bailey, R.H.; Kubena, L.F.; Harvey, R.B.; Buckley, S.A.; Rottinghaus, G.E. Efficacy of various inorganic sorbents to reduce the toxicity of aflatoxin and T-2 toxin in broiler chickens. Poult. Sci. 1998, 77, 1623-1630. [CrossRef]

107. Awad, W.; Ghareeb, K.; Böhm, J.; Zentek, J. Decontamination and detoxification strategies for the Fusarium mycotoxin deoxynivalenol in animal feed and the effectiveness of microbial biodegradation. Food Addit. Contam. Part A 2010, 27, 510-520. [CrossRef]

108. Devegowda, G.; Ravikiran, D. Mycotoxins and eggshell quality: Cracking the problem. World Mycotoxin J. 2008, 1, 203-208. [CrossRef]

109. Rizzi, L.; Simioli, M.; Roncada, P.; Zaghini, A. Aflatoxin B1 and Clinoptilolite in Feed for Laying Hens: Effects on Egg Quality, Mycotoxin Residues in Livers, and Hepatic Mixed-Function Oxygenase Activities. J. Food Prot. 2003, 66, 860-865. [CrossRef]

110. Lee, J.T.; Jessen, K.A.; Beltran, R.; Starkl, V.; Schatzmayr, G.; Borutova, R.; Caldwell, D.J. Mycotoxin-contaminated diets and deactivating compound in laying hens: 1. Effects on performance characteristics and relative organ weight. Poult. Sci. 2012, 91, 2089-2095. [CrossRef]

111. Del Bianchi, M.; Oliveira, C.A.F.; Albuquerque, R.; Guerra, J.L.; Correa, B. Effects of prolonged oral administration of aflatoxin B1 and fumonisin B1 in broiler chickens. Poult. Sci. 2005, 84, 1835-1840. [CrossRef] [PubMed]

112. Tardieu, D.; Travel, A.; Metayer, J.-P.; Le Bourhis, C.; Guerre, P. Zearalenone and Metabolites in Livers of Turkey Poults and Broiler Chickens Fed with Diets Containing Fusariotoxins. Toxins 2020, 12, 525. [CrossRef] [PubMed]

113. Tardieu, D.; Travel, A.; Metayer, J.-P.; Le Bourhis, C.; Guerre, P. Fumonisin B1, B2 and B3 in Muscle and Liver of Broiler Chickens and Turkey Poults Fed with Diets Containing Fusariotoxins at the EU Maximum Tolerable Level. Toxins 2019, 11, 590. [CrossRef] [PubMed]

114. Anyango, G.; Kagera, I.; Mutua, F.; Kahenya, P.; Kyallo, F.; Andang'O, P.; Grace, D.; Lindahl, J. Effectiveness of Training and Use of Novasil Binder in Mitigating Aflatoxins in Cow Milk Produced in Smallholder Farms in Urban and Periurban Areas of Kenya. Toxins 2021, 13, 281. [CrossRef]

115. Mutua, F.; Lindahl, J.; Grace, D. Availability and use of mycotoxin binders in selected urban and Peri-urban areas of Kenya. Food Secur. 2019, 11, 359-369. [CrossRef]

116. Ayo, E.M.; Matemu, A.; Laswai, G.H.; Kimanya, M.E. An In Vitro Evaluation of the Capacity of Local Tanzanian Crude Clay and Ash-Based Materials in Binding Aflatoxins in Solution. Toxins 2018, 10, 510. [CrossRef] [PubMed] 
117. Dwyer, M.R.; Kubena, L.; Harvey, R.; Mayura, K.; Sarr, A.; Buckley, S.; Bailey, R.; Phillips, T. Effects of inorganic adsorbents and cyclopiazonic acid in broiler chickens. Poult. Sci. 1997, 76, 1141-1149. [CrossRef]

118. Bhatti, S.A.; Khan, M.Z.; Hassan, Z.U.; Saleemi, M.K.; Saqib, M.; Khatoon, A.; Akhtar, M. Comparative efficacy of Bentonite clay, activated charcoal and Trichosporon mycotoxinivorans in regulating the feed-to-tissue transfer of mycotoxins: Regulating Mycotoxins Deposition in Liver. J. Sci. Food Agric. 2018, 98, 884-890. [CrossRef] [PubMed]

119. Miazzo, R.; Rosa, C.A.R.; De Queiroz Carvalho, E.C.; Magnoli, C.; Chiacchiera, S.M.; Palacio, G.; Saenz, M.; Kikot, A.; Basaldella, E.; Dalcero, A. Efficacy of synthetic zeolite to reduce the toxicity of aflatoxin in broiler chicks. Poult. Sci. 2000, 79, 1-6. [CrossRef] [PubMed]

120. Ma, Q.G.; Gao, X.; Zhou, T.; Zhao, L.H.; Fan, Y.; Li, X.Y.; Lei, Y.P.; Ji, C.; Zhang, J.Y. Protective effect of Bacillus subtilis ANSB060 on egg quality, biochemical and histopathological changes in layers exposed to aflatoxin B1. Poult. Sci. 2012, 91, 2852-2857. [CrossRef] [PubMed]

121. Schatzmayr, G.; Zehner, F.; Täubel, M.; Schatzmayr, D.; Klimitsch, A.; Loibner, A.P.; Binder, E.M. Microbiologicals for deactivating mycotoxins. Mol. Nutr. Food Res. 2006, 50, 543-551. [CrossRef] [PubMed]

122. EFSA Panel on Additives and Products or Substances used in Animal Feed (FEEDAP); Rychen, G.; Aquilina, G.; Azimonti, G.; Bampidis, V.; de Lourdes Bastos, M.; Bories, G.; Chesson, A.; Cocconcelli, P.S.; Flachowsky, G.; et al. Safety and Efficacy of Fumonisin Esterase (FUMzyme ${ }^{\circledR}$ ) as a Technological Feed Additive for All Avian Species. EFSA J. 2016, 14, e04617. [CrossRef]

123. Pfohl-Leszkowicz, A.; Hadjeba-Medjdoub, K.; Ballet, N.; Schrickx, J.; Fink-Gremmels, J. Assessment and characterisation of yeast-based products intended to mitigate ochratoxin exposure usingin vitroandin vivomodels. Food Addit. Contam. Part A 2015, 32, 604-616. [CrossRef] [PubMed]

124. Molnar, O.; Schatzmayr, G.; Fuchs, E.; Prillinger, H. Trichosporon mycotoxinivorans sp. nov., A New Yeast Species Useful in Biological Detoxification of Various Mycotoxins. Syst. Appl. Microbiol. 2004, 27, 661-671. [CrossRef] 